University of Nebraska - Lincoln

DigitalCommons@University of Nebraska - Lincoln

\title{
Comparison of local- to regional-scale estimates of ground-water recharge in Minnesota, USA
}

\author{
Geoffrey N. Delin \\ US Geological Survey \\ Richard W. Healy \\ US Geological Survey \\ David L. Lorenz \\ US Geological Survey \\ John R. Nimmo \\ US Geological Survey
}

Follow this and additional works at: https://digitalcommons.unl.edu/usgsstaffpub

Part of the Earth Sciences Commons

Delin, Geoffrey N.; Healy, Richard W.; Lorenz, David L.; and Nimmo, John R., "Comparison of local- to regional-scale estimates of ground-water recharge in Minnesota, USA" (2007). USGS Staff -- Published Research. 213.

https://digitalcommons.unl.edu/usgsstaffpub/213

This Article is brought to you for free and open access by the US Geological Survey at DigitalCommons@University of Nebraska - Lincoln. It has been accepted for inclusion in USGS Staff -- Published Research by an authorized administrator of DigitalCommons@University of Nebraska - Lincoln. 


\title{
Comparison of local- to regional-scale estimates of ground-water recharge in Minnesota, USA
}

\author{
Geoffrey N. Delin ${ }^{a, *}$, Richard W. Healy ${ }^{b}$, David L. Lorenz ${ }^{a}$, John R. Nimmo ${ }^{c}$
}

a US Geological Survey, 2280 Woodale Drive, Mounds View, MN 55112, United States

b US Geological Survey, Denver Federal Center, MS413, Building 53, Lakewood, CO 80225, United States

c US Geological Survey, 345 Middlefield Road, MS 421, Menlo Park, CA 94025, United States

Received 3 February 2006; received in revised form 3 October 2006; accepted 11 October 2006

\section{KEYWORDS \\ Recharge; \\ Ground water; \\ Unsaturated zone; \\ Model; \\ Soil moisture}

\begin{abstract}
Summary Regional ground-water recharge estimates for Minnesota were compared to estimates made on the basis of four local- and basin-scale methods. Three local-scale methods (unsaturated-zone water balance, water-table fluctuations (WTF) using three approaches, and age dating of ground water) yielded point estimates of recharge that represent spatial scales from about 1 to about $1000 \mathrm{~m}^{2}$. A fourth method (RORA, a basin-scale analysis of streamflow records using a recession-curve-displacement technique) yielded recharge estimates at a scale of $10-1000 \mathrm{~s}$ of $\mathrm{km}^{2}$. The RORA basin-scale recharge estimates were regionalized to estimate recharge for the entire State of Minnesota on the basis of a regional regression recharge (RRR) model that also incorporated soil and climate data. Recharge rates estimated by the RRR model compared favorably to the local and basin-scale recharge estimates. RRR estimates at study locations were about $41 \%$ less on average than the unsaturated-zone water-balance estimates, ranged from $44 \%$ greater to $12 \%$ less than estimates that were based on the three WTF approaches, were about $4 \%$ less than the age dating of ground-water estimates, and were about $5 \%$ greater than the RORA estimates. Of the methods used in this study, the WTF method is the simplest and easiest to apply. Recharge estimates made on the basis of the UZWB method were inconsistent with the results from the other methods. Recharge estimates using the RRR model could be a good source of input for regional ground-water flow models; RRR model results currently are being applied for this purpose in USGS studies elsewhere.

(c) 2006 Elsevier B.V. All rights reserved.
\end{abstract}

\footnotetext{
* Corresponding author. Tel.: +1 763783 3231; fax: +1 763783 3103.

E-mail addresses: delin@usgs.gov (G.N. Delin), rwhealy@usgs. gov (R.W. Healy), lorenz@usgs.gov (D.L. Lorenz), jrnimmo@usgs. gov (J.R. Nimmo).
}

\section{Introduction}

Knowledge of ground-water recharge is critical in virtually all ground-water hydrology investigations ranging from studies of agricultural contamination (Böhlke, 2002), urban

0022-1694/\$ - see front matter (c) 2006 Elsevier B.V. All rights reserved.

doi:10.1016/j.jhydrol.2006.10.010 
transport (Lerner, 2002), and aquifer vulnerability (Robins, 1998) to hazardous-waste disposal siting (Tyler et al., 1996; Scanlon et al., 1997). Ground-water recharge is defined herein as the entry into the saturated zone of water made available at the water-table surface (Freeze and Cherry, 1979). Associated with this recharge is ground-water movement within the saturated zone away from the water-table area where the recharge occurred. Recharge is the variable that ground-water flow modelers typically know the least about but to which the simulated results from the model are most sensitive. Accurate estimation of recharge is difficult because the processes are complex and depend on numerous local factors, including precipitation amount, intensity, and duration, evapotranspiration rate, runoff, geology, soil characteristics, topography, vegetation, and land use (Memon, 1995). Application of multiple methods is recommended in estimating recharge because of the limitations inherent in each method (Healy and Cook, 2002; Scanlon et al., 2002; Nimmo et al., 2005). For example, Risser et al. (2005) had sufficient data to estimate recharge using four methods within a small watershed in Pennsylvania. It is rare, however, to have sufficient good-quality data to allow recharge estimation using more than two or three methods.

There are significant differences in local- and regionalscale estimates of recharge. Local-scale estimates generally are not representative of an entire watershed, and regional estimates may be too general to capture recharge variability within a watershed. Methods used in humid areas typically are based on streamflow, water-table fluctuations, or water-balance approaches (Scanlon et al., 2002), which work best where the water table is relatively shallow and streams typically are gaining. Tracers and age-dating techniques have also been used in both unsaturated and saturated zone studies to estimate recharge (e.g. Gvirtzman et al., 1986; Delin et al., 2000). Several different approaches have been used recently to estimate recharge at the regional scale in humid areas of the United States, resulting in maps that illustrate spatial variability of recharge (e.g. Sophocleous, 1992; Holtschlag, 1996; Arnold et al., 2000; Dumouchelle and Schiefer, 2002; Szilagyi et al., 2005). Few studies, however, have compared results of a regional approach to multiple local-scale values. Such a comparison is needed to help determine the applicability of regional-scale estimates at the local scale.

The regional regression recharge (RRR) estimation method of Lorenz and Delin (2007) provides a method for regionalizing recharge estimates at the local or basin scale to estimates over a large region. To fully demonstrate the usefulness and accuracy of the RRR model, however, results need to be compared to local- and basin-scale recharge estimates made with well-documented methods. This paper makes this scale comparison by using climate, streamflow, soil, unsaturated-zone, ground-water level, and groundwater age data for Minnesota, USA, to estimate recharge at different spatial and temporal scales. The methods compared to the RRR method in this paper include an unsaturated-zone water-balance (UZWB), three water-table fluctuation (WTF) approaches, age dating of ground water, and the RORA method (Rutledge, 1998, 2000), a basin-scale analysis of streamflow records using a recession-curve-displacement technique. This paper also evaluates the spatial and temporal variability of recharge using the various methods.

\section{Methods}

\section{Location and description of study area}

The study area encompasses the entire State of Minnesota (Fig. 1). Shown in Fig. 1 are the stream basin locations and well sites where ground-water data were obtained for this study. Water in this headwaters State drains to the Mississippi River in the central and southeastern parts; drains to the Red River of the North in the northwest part; and drains to Lake Superior in the northeast part. The State is largely covered by glacial deposits of the Late Wisconsin glaciation (Sims and Morey, 1972). The glacial deposits range in thickness from less than $6 \mathrm{~m}$ in the southeast and northeast to greater than $180 \mathrm{~m}$ in bedrock valleys. Upland parts of the State typically consist of clayey till, whereas glacial outwash covers broad, generally flat sand plains. The topography and sediments vary greatly across the State. At most of the sites where water-level data were collected for this study, however, topography is generally flat to gently rolling. Sediments at most of the sites typically consisted of poorly sorted glacial outwash sand of fine to very coarse grain size, with some fine gravel and cobbles. Water-table depths varied from less than 1 to about $54 \mathrm{~m}$ at the sites used in this study. Land use typically was agricultural in the glacial outwash areas where most of the data were collected.

Mean annual precipitation (1971-2000) across the State ranges between about 50 and $90 \mathrm{~cm} / \mathrm{yr}$ (Gregory Spoden, Minnesota Department of Natural Resources, written commun., 2003). About $60 \%$ of this precipitation falls during the growing season (May-September). Mean annual runoff ranges from 5 to $41 \mathrm{~cm} / \mathrm{yr}$ (Baker et al., 1979). Mean monthly temperatures (1951-1980) vary from about $22^{\circ} \mathrm{C}$ in July to about $-16^{\circ} \mathrm{C}$ in January (Baker et al., 1985).

\section{Recharge estimation}

Many methods can be used to estimate recharge in humid regions (Scanlon et al., 2002). These methods range from site-specific, where localized unsaturated-zone or saturated-zone data are available, to ground-water mass balance estimates at the basin scale. It was beyond the scope of this study, and data were insufficient, to use all of the available methods. The methods employed were based largely on data collected during previous studies. The hydrologic data and methods used in this study represent different spatial and temporal scales (Table 1). The climate and geology of Minnesota generally prevent the unsaturated zone from being more than a few $m$ thick, and recharging water generally requires less than a year to travel from the surface to the water table. Such relatively short travel times preclude use of the unsaturated-zone tracer methods (e.g. measuring the depth to the 1963 tritium peak) that work on timescales of several decades. Rapid passage through the unsaturated zone works to the advantage of saturated-zone age-dating tracer methods, however. The four methods used in this study were: (1) unsaturated-zone 


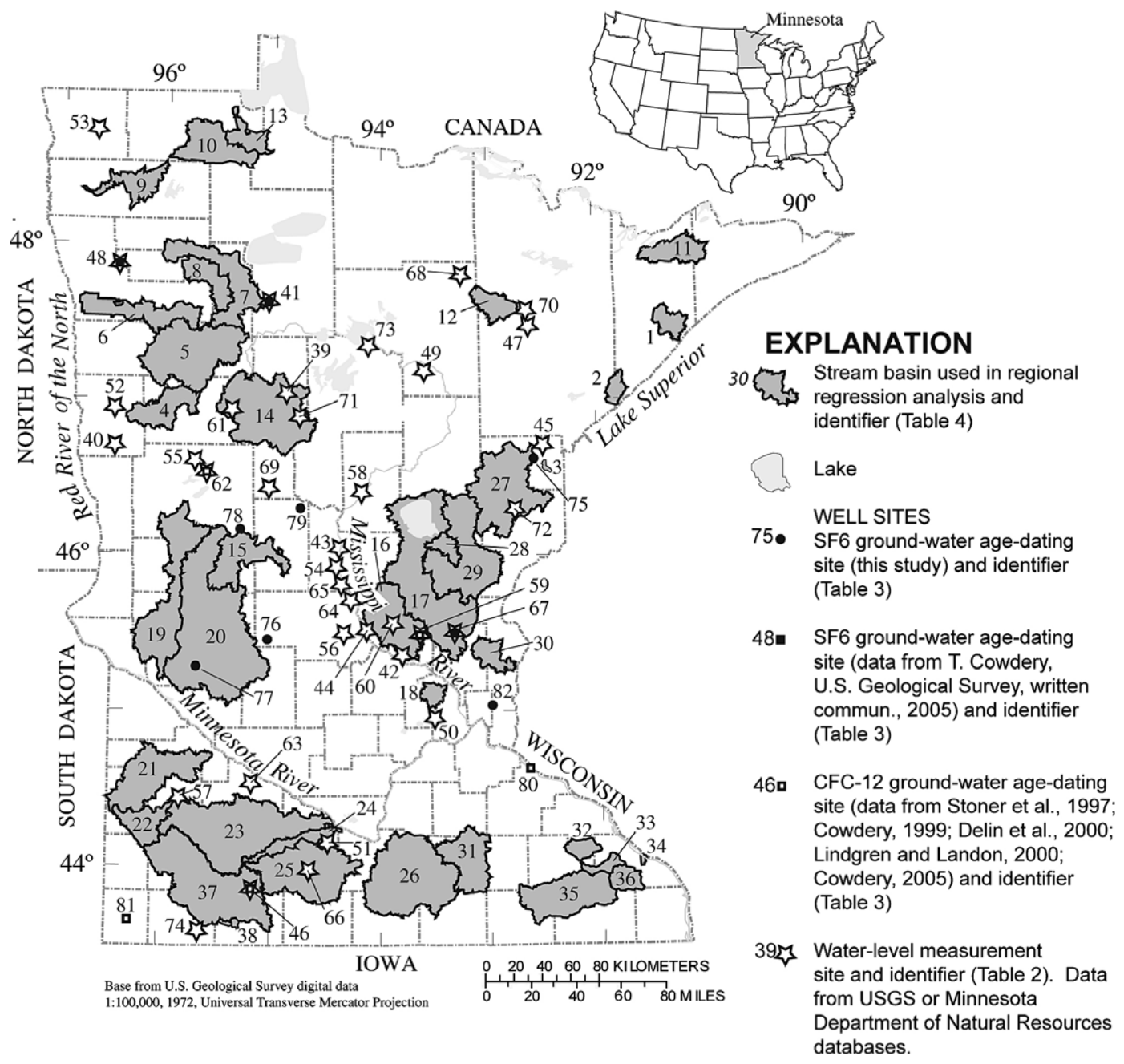

Figure 1 Location of intensive data-collection sites for the water-table fluctuation (WTF) method and the ground-water agedating method, and basins used in the regional regression recharge method. Note that water-level measurement and ground-water age dating are coincidental for several sites.

Table 1 Methods used for estimating ground-water recharge in this study

\begin{tabular}{lll}
\hline Method & Spatial scale represented & Temporal scale represented \\
\hline Unsaturated-zone water balance (UZWB) & $1 \mathrm{~m}^{2}$ & Event based to seasonal \\
Water-table fluctuation (WTF) & $1-100 \mathrm{~s} \mathrm{~m}^{2}$ & Event based to seasonal \\
Age dating of ground water & $1-1000 \mathrm{~s} \mathrm{~m}^{2}$ & $1-50$ year average \\
RORA analysis of streamflow records using & $100-1000 \mathrm{~s} \mathrm{~km}$ & Monthly-100 years; \\
a recession-curve-displacement technique & & period of record
\end{tabular}

Modified from Scanlon et al. (2002); RORA, (Rutledge, 1998, 2000) is an automated method for estimating recharge in a basin from analysis of a streamflow record using the recession-curve-displacement method of Rorabaugh $(1960,1964)$.

water balance (UZWB), which utilizes soil-moisture data, (2) water-table fluctuations (WTF), (3) age dating of water in the saturated zone, and (4) RORA, a basin-scale analysis of streamflow records using a recession-curve-displacement technique.

\section{Unsaturated-zone water-balance (UZWB) method}

The UZWB method relies on soil-moisture data from a single profile within the unsaturated zone, representing about $1 \mathrm{~m}^{2}$, with a temporal scale that is event-based to seasonal
(Delin et al., 2000; Delin and Herkelrath, 2005). This method is based on the premise that soil water moves upward in response to evapotranspiration (ET) above a boundary in the unsaturated zone and that water below that depth percolates downward to the water table as a result of each recharge period. Water that infiltrates into the "recharge zone" below the ET/drainage boundary is assumed to be unavailable for ET and ultimately results in recharge. Data for the UZWB recharge estimates were available from three intensive USGS data-collection sites - near Bemidji (1998- 
2003), Williams Lake (1998-2003) (D. Hudson, US Geological Survey, written commun., 2004), and the Management Systems Evaluation Area (Princeton) site (1992-1995) (Delin et al., 1997) (Fig. 1). The ET/drainage boundary was located at the $100-\mathrm{cm}$ depth at all three sites, based on soil tension measurements at the Bemidji site and on plant rooting depth research results at the other two sites.

To estimate recharge using the UZWB method, the total volume of soil moisture in the recharge zone per unit cross section $\left(V ; \mathrm{cm}^{3} / \mathrm{cm}^{2}\right)$, was estimated throughout the year:

$\boldsymbol{V}=\sum_{i=1}^{M} \theta_{i} \Delta \mathbf{z}_{i}$,

where $i$ is an index to the soil-moisture probes (numbered sequentially from 1 for the probe nearest the water table to $M$ for the probe nearest the ET/drainage boundary), $\theta_{i}$ is the soil-moisture content measured by probe $i\left(\mathrm{~cm}^{3} /\right.$ $\mathrm{cm}^{3}$ ); and $\Delta z_{i}$ is the vertical thickness of the unsaturated zone associated with probe $i(\mathrm{~cm})$. Recharge was assumed to occur as a series of events in response to precipitation. The recharge period $\left(R_{j} ; \mathrm{cm}\right)$ was calculated as the increase in $V$ that occurred during recharge period $j$ :

$R_{j}=V_{j \max }-V_{j \text { ant }}$,

where $V_{j \max }$ is the maximum total soil-moisture volume measured during the recharge period $\left(\mathrm{cm}^{3} / \mathrm{cm}^{2}\right)$, and $V_{j a n t}$ is the minimum total soil moisture volume measured immediately before the recharge period $\left(\mathrm{cm}^{3} / \mathrm{cm}^{2}\right)$. Total annual recharge $\left(R_{\text {Total }} ; \mathrm{cm} / \mathrm{yr}\right)$ is assumed to equal the sum of the individual recharge events during the year.

\section{Water-table fluctuation (WTF) method}

The WTF method synthesizes data on a spatial scale of $1-$ 100 s of $\mathrm{m}^{2}$ with a temporal scale that is period-based to seasonal. The method is based on relating changes in measured water-table elevation with changes in the amount of water stored in the aquifer (Meinzer, 1923; Healy and Cook, 2002):

$R\left(t_{j}\right)=\mathrm{Sy}^{*} \Delta H\left(t_{j}\right)$

where $R\left(t_{j}\right)(\mathrm{cm})$ is recharge occurring between times $t_{0}$ and $t_{j}$, Sy is specific yield (dimensionless), and $\Delta H\left(t_{j}\right)$ is the peak water-table rise attributed to the recharge period $(\mathrm{cm})$. Inherent assumptions include: (1) the observed well hydrograph depicts only natural water-table fluctuations caused by ground-water recharge and discharge; (2) Sy is known and constant over the interval of the water-table fluctuations, and (3) the pre-recharge water-level recession can be extrapolated to determine $\Delta H\left(t_{j}\right)$.

Water-level data used in the WTF method were collected from a variety of sites across Minnesota (Fig. 1). The USGS has conducted intensive, long-term research at five sites that yielded 1-10 years of continuous (meaning collected at intervals no longer than 1 day) ground-water level data for 29 wells: Bemidji - 8 wells (1993-2003); Princeton 4 wells (1992-1995); Williams Lake - 9 wells (19982003), Des Moines River - 4 wells (1999-2001); Glacial Ridge -4 wells (2003). Because wells were closely spaced at these sites, results in this paper are generally presented as an average for each site. Additional water-level data were obtained from the Minnesota Department of Resources (MDNR) observation well network (T. Gullett, Minnesota
Department of Resources, written commun., 2003). Only wells with at least a weekly water-level measurement interval throughout a given year were used. Thirty-four MDNR wells at 31 sites met these criteria, with most of the data collected before 1980 . Where data were available only in analog form, one value from every fifth day was entered manually into a database. The fact that the water-level data from the various WTF sites represent different time periods imposes a bias on recharges estimates toward the climate of that respective time period.

$\Delta H\left(t_{j}\right)$ is estimated as the difference between the peak of a water-level rise and the value of the extrapolated antecedent recession curve at the time of the peak. This recession curve is the trace that the well hydrograph would have followed had there not been any precipitation (Fig. 2). Predicting the recession curve is not always straightforward. Two approaches were used to estimate $\Delta H\left(t_{j}\right)$ in the WTF method: (1) graphical extrapolation and (2) calculation from a master recession curve (MRC). A third approach used to estimate $\Delta H\left(t_{j}\right)$, made on the basis of the computer code from the RISE program (A. Rutledge, US Geological Survey, written commun., 2005), does not extrapolate for continuation of a hypothetical recession while the water table is rising. Because of the need for daily water-level data, the MRC and RISE approaches could be applied only at sites where water levels were continuously monitored. These two methods are described in detail in the following sections.

Limitations of the WTF method include the fact that water-level fluctuations in a well may only be representative of a small area within a watershed (hence the previously described averaging scheme for some sites); waterlevel rises may not always be the result of direct recharge (water levels in some wells at the Des Moines River site, for example, may have been influenced by river stage); and the method assumes that recharge is episodic and therefore does not account for slow, steady flow to a water table that may occur in regions with thick unsaturated zones. This last item is probably not an issue in a region such as this where depth to the water table is generally less than $10 \mathrm{~m}$. Uncertainty in estimates of Sy

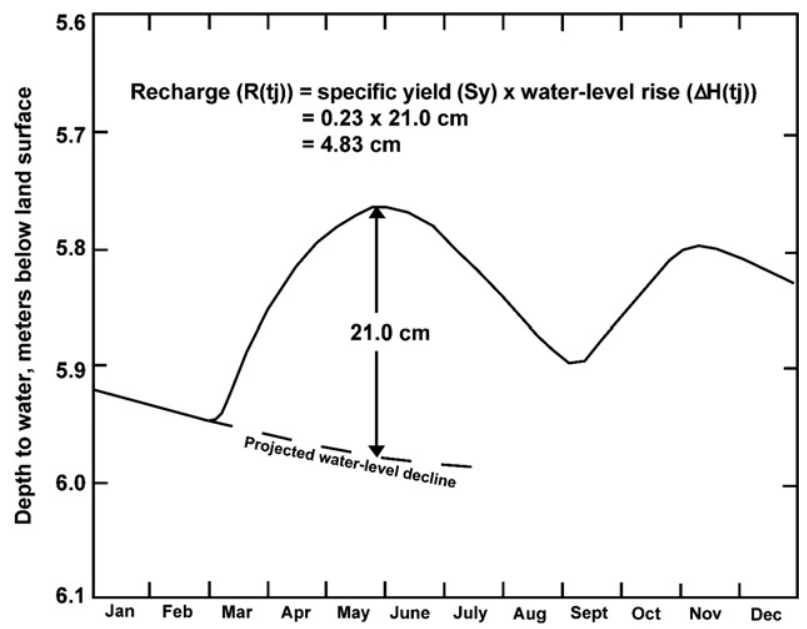

Figure 2 Recharge estimated using the graphical approach to the WTF method, illustrated with hypothetical data. 
is also a concern. For this study, following common practice, Sy was set at a constant value. In reality Sy varies as a function of depth to the water table (Childs, 1960). It also varies over time in response to the wetting and draining history. If multiple rises occur closely spaced in time, the sediments may not fully drain between rises. In theory, it would be appropriate to assign different values of Sy to different rises. In practice, however, the information and resources required to make these accommodations are rarely available.

WTF method - graphical approach. In the graphical approach used in the WTF method the antecedent recession curves were extrapolated manually to obtain $\Delta H\left(t_{j}\right)$ (Fig. 2) on the basis of visual inspection of the entire data set. When viewed with corresponding precipitation data, rises that were not caused by precipitation (and therefore did not indicate recharge) could be identified clearly and eliminated from the recharge calculations. Examples of rises not caused by precipitation include electrical surges, changes in barometric pressure, pumping, earth tide effects, entrapped air, temperature variations, and manual adjustment to the water-level measuring device. This approach involved more subjectivity than the other WTF approaches, and different users no doubt would produce slightly different recession curves.

0.0.0.1. WTF method - master recession curve (MRC) approach. The MRC approach used in the WTF method was an automated procedure for calculating $\Delta H\left(t_{j}\right)$ from daily water-level data. The antecedent recession curve was determined from a nonlinear regression equation of the log of the difference in altitude between the water level and the "pour point," the asymptote that the water-level recession is approaching. Development of a MRC began by generating a list of recessions (periods during which ground-water levels continually decrease) for a given well using a program called FALL (A. Rutledge, US Geological Sur- vey, written commun., 2003). A minimum recession duration of 10 days was chosen in this study. Once a list of recessions was tabulated for the entire period of record, statistical analysis software S-Plus ${ }^{\circledR}$ was used to estimate the MRC recession parameters $d$ and RR from the following nonlinear relation:

$\ln \left(H_{t}-d\right)=\ln \left(H_{0}-d\right)+\mathrm{RR}^{*} t$

where $H_{t}$ is water level at the end of the recession $(\mathrm{cm}), d$ is the water level or pour point at which no discharge occurs $(\mathrm{cm}), H_{0}$ is the water level at the start of the recession $(\mathrm{cm}), \mathrm{RR}$ is the recession rate (which is negative) $(\ln (\mathrm{cm}) /$ $\mathrm{d})$; and $t$ is the time of the recession (days). The negative reciprocal of $R R$ is the time in days for a decrease of one natural log cycle in the water table above $d$. With a MRC thus derived, the MRC was applied to the same daily ground-water levels used by the RISE program. The MRC was projected from the first ground-water value in the record. If the subsequent ground-water level rose above this projected recession, recharge was measured as the distance from the projected MRC to the shallower ground-water level. From this point, a new MRC was drawn, and the process repeated (Fig. 3).

Even though multiple steps were required, the MRC approach was straightforward and easy to apply. The approach avoided subjectivity after the estimation of the MRC parameters, but there remained the possibility that water-level rises that were not due to recharge may have been improperly included in the calculations. Other automated approaches to approximating the antecedent recession curve include those by Crosbie et al. (2005) and Heppner and Nimmo (2005).

WTF method - RISE program approach. The RISE program approach (A. Rutledge, US Geological Survey, written commun., 2003) used in the WTF method calculated the daily rise of water levels in an observation well as the amount by which the water level on that day exceeded that of the

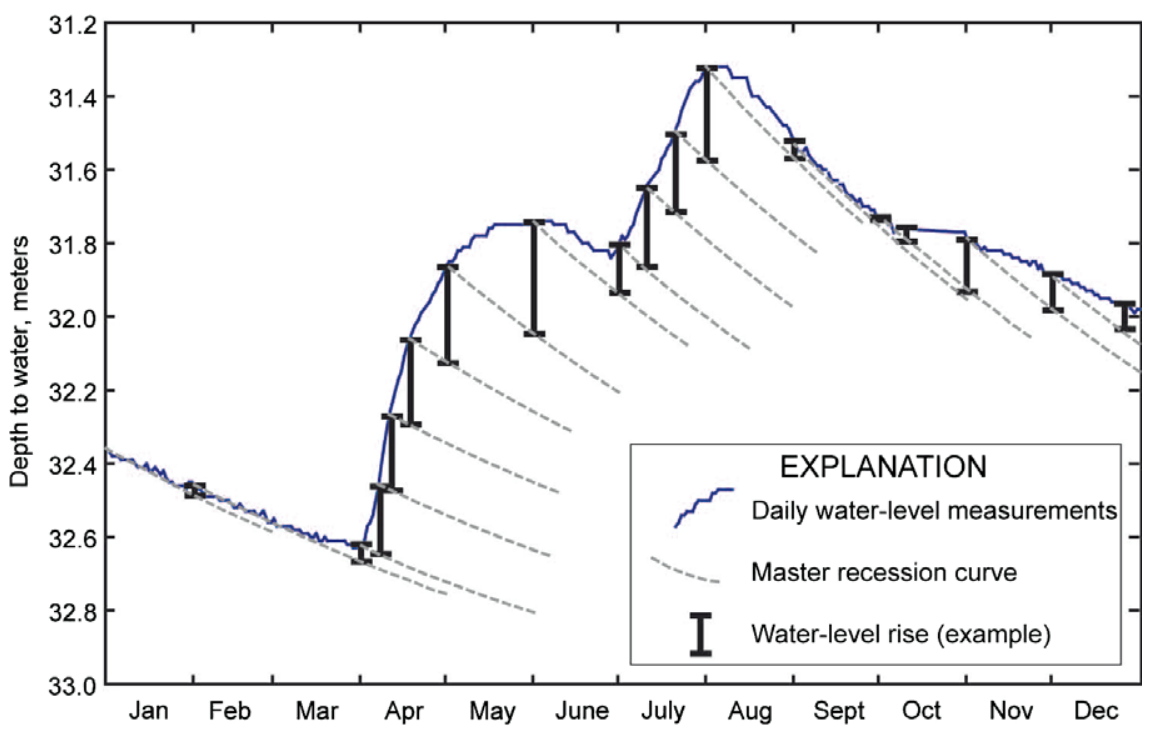

Figure 3 Recharge estimated using the master recession curve (MRC) approach to the WTF method. In practice, the MRC is applied to every data point in the record. For clarity only selected applications of the MRC are illustrated on this figure. 
previous day. If the result was negative, it was set to zero for that day. This approach was expected to underestimate actual recharge rates because the program makes no allowance for the hydrograph recession that would have occurred in the absence of recharge. The approach was very easy to apply and involved less subjectivity than the other approaches. For example, the approach is automated and the scientist does not need to make a judgment based on previous experience to extrapolate the recession curve for each recharge event.

Specific yield. Specific yield (Sy) for the WTF method was estimated using a water-budget approach (Walton, 1970; Hall and Risser, 1993; Healy and Cook, 2002). For late fall through early spring, rates of ET in Minnesota are small, and soil-moisture contents are usually at their greatest level. During this time period, assuming ET and change in soil-moisture storage are negligible:

$P=R+\mathrm{RO}$,

where $P$ is precipitation from a particular storm $(\mathrm{cm}) ; R$ is recharge $(\mathrm{cm})$; and RO is surface runoff $(\mathrm{cm})$. This equation states that precipitation either percolates down to the water table as recharge or runs off. The method requires data on water levels, precipitation, and stream discharge. Inserting Eq. (3) into Eq. (5) and rearranging yields:

Sy $=(P-\mathrm{RO}) / \Delta H\left(t_{j}\right)$.

Eq. (6) was applied to all precipitation-induced water-level rises for each well from late fall through early spring. Streamflow records from nearest USGS gaging stations were used to estimate surface runoff. For most of these events, runoff was no more than a few percent of total precipitation. Therefore to facilitate calculations, RO was considered to be zero in Eq. (6). Large storm events with substantial runoff were omitted from the Sy calculations. This approach may produce a slight overestimation in Sy.

Calculating Sy using Eq. (6) required diligence. Some periods of precipitation produced anomalously small water-level rises. The most common reason for this was precipitation falling as snow. Snowmelt, on the other hand, could produce large ground-water level rises with little or no precipitation immediately before the rise. To minimize the effects of these two extremes, air temperature data were used in conjunction with precipitation data to identify and remove periods of snowfall and snowmelt from the analysis. For each well, application of Eq. (6) produced a value of Sy for each appropriate recharge period. If the median Sy value was selected as the representative value for each well, then recharge calculated using Eq. (3) would exceed precipitation for one-half of the winter recharge periods. Although such an occurrence could happen (if, for instance, the well is located in a surface depression), it is unreasonable to believe that this would occur half of the time for all of the wells. As a compromise, the representative value of Sy for each well was set equal to the average of all values that occurred within the lowest 20th percentile of the set of Sy values for that well; that is, average of the $n / 5$ smallest of the set of $n$ values. Because each of these values should be legitimate independently, it was not unreasonable to select a subset of them for further use.

\section{Age dating of ground water method}

The age dating of ground water method synthesized data on a spatial scale of $1-1000$ s of $\mathrm{m}^{2}$ (Delin et al., 2000). Recharge generally could not be estimated for a single recharge period. Ground-water ages (the time elapsed since the water entered the aquifer as recharge) can be used with well-depth information to obtain a vertical ground-water velocity (Vogel, 1967; Delin et al., 2000). The velocity was multiplied by aquifer porosity to obtain a recharge rate estimate. This method was limited in its spatial resolution because deeper water, needed to establish an age gradient at a site, may represent water recharged at increasingly greater distances upgradient from the site. Ground-water ages were determined on the basis of concentrations of chlorofluorocarbon (CFC-12) and sulfur-hexafluoride $\left(\mathrm{SF}_{6}\right)$ using techniques documented by Busenberg and Plummer $(1992,2000)$. These constituents can be used to trace the flow of young water at the 1- to 50-year time scale as of 2005, depending on the ground-water age-dating method used and the length and depth of the screened interval in each well.

The recharge dates of ground water at one or more depths below the water table were estimated for this study from measured concentrations of $\mathrm{SF}_{6}$ at eight sites (Fig. 1). Recharge dates were also estimated from measured concentrations of $\mathrm{SF}_{6}$ at one site collected from a previous study (T. Cowdery, US Geological Survey, written commun., 2004) and from measured concentrations of CFC-12 at 5 sites collected during previous studies (Stoner et al., 1997; Cowdery, 1999; Delin et al., 2000; Lindgren and Landon, 2000; Cowdery, 2005). Recharge dates were obtained from three or more depths at the Bemidji and Princeton sites, and vertical ground-water velocities at the water table $\left(V_{v}^{\circ}\right)$ were estimated visually by assuming an exponential age distribution in the surficial aquifer (Vogel, 1967; Delin et al., 2000):

$V_{\mathrm{v}}^{\mathrm{o}}=(Z / \operatorname{age}(i))^{*} \ln \{Z /[Z-z(i)]\}$,

where $Z$ is thickness of the saturated zone in the surficial aquifer $(\mathrm{cm})$, and $z(i)$ is depth of the parcel below the water table $(\mathrm{cm})$. The average saturated-zone porosity at the site $(\phi)$ based on gravimetric analyses was used to convert the vertical velocities at the water table $\left(V_{v}^{\circ}\right)$ to ground-water recharge rates:

$R=\phi V_{\mathrm{v}}^{\circ}$,

The Sy values calculated in the previous section typically were $30-50 \%$ less than the $\phi$ numbers. For the other sites where only a single ground-water age was available, a linear ground-water age-depth profile was used to estimate downward vertical ground-water velocity at the water table $\left(V_{v}^{o}\right.$; $\mathrm{cm} / \mathrm{yr})$ :

$V_{\mathrm{v}}^{\mathrm{o}}=\mathrm{z} /$ age,

where $z$ is the depth of the middle of the well screen $(\mathrm{cm})$, and age is the age of a ground-water parcel (years).

\section{RORA method}

RORA (Rutledge, 1998, 2000) is an automated method for estimating recharge in a basin from analysis of a streamflow record using the recession-curve-displacement method of 
Rorabaugh $(1960,1964)$. The RORA program accounts for the effects of ET, underflow, and other losses or gains of ground water following a precipitation event. The RORA program and associated documentation is available on the web at: http://water.usgs.gov/ogw/rora/.

Before ground-water recharge could be estimated using the RORA method, all 340 continuous-record stream-gaging records in Minnesota were accessed through NWISWeb (http://waterdata.usgs.gov/mn/nwis/sw) and reviewed for inclusion in the analysis. The criteria for inclusion were (1) gaging stations have at least a 10-year period of record; (2) gaging stations have no missing data within the 10-year periods; (3) the flow cannot be affected significantly by regulation and diversion structures, such as a dam; (4) the ba- sins lie wholly within Minnesota or have soils that are not different from those found in Minnesota; (5) the basins have a drainage area of less than $5000 \mathrm{~km}^{2}$; (6) if a basin is nested within a larger basin, it must be restricted to less than $15 \%$ of the larger basin; and (7) the basins have soil data that can be used to estimate landscape characteristics. The first criterion was needed to obtain good average recharge estimates, criteria 3 and 6 were included to simplify processing and analysis, and criteria 2, 4, and 5 were required for estimating recharge. On the basis of above criteria, a total of 38 basins were selected for use (Fig. 1; Table 2). One possible error inherent to the method is that RORA assumed that the streamflow recession is caused by ground-water discharge, which might not necessarily be the case. Slow runoff from

Table 2 Average recharge rates as a percentage of precipitation using the RORA method in comparison to estimated recharge from the regional regression recharge (RRR) model

\begin{tabular}{|c|c|c|c|c|c|c|}
\hline $\begin{array}{l}\text { Map ref. } \\
\text { no. }\end{array}$ & USGS stream gaging station (basin) name & $\begin{array}{l}\text { Gaging station } \\
\text { number }\end{array}$ & $\begin{array}{l}\text { Period } \\
\text { analyzed }\end{array}$ & $\begin{array}{l}\text { Average precip. } \\
(\mathrm{cm} / \mathrm{yr})\end{array}$ & RORA (\%) & RRR (\%) \\
\hline 1 & Baptism River near Beaver Bay & 4014500 & $1950-1989$ & 78 & 44 & 21 \\
\hline 2 & Knife River near Two Harbors & 4015330 & 1980-1999 & 76 & 34 & 18 \\
\hline 3 & Deer Creek near Holyoke & 4024098 & $1980-1999$ & 78 & 24 & 21 \\
\hline 4 & Buffalo River near Hawley & 5061000 & $1950-1999$ & 64 & 13 & 11 \\
\hline 5 & Wild Rice River at Twin Valley & 5062500 & $1940-1999$ & 63 & 13 & 30 \\
\hline 6 & Sand Hill River near Climax & 5069000 & 1950-1999 & 60 & 10 & 19 \\
\hline 7 & Clearwater River at Plummer & 5078000 & 1940-1999 & 62 & 16 & 35 \\
\hline 8 & Lost River at Oklee & 5078230 & 1970-1999 & 62 & 15 & 17 \\
\hline 9 & Middle River at Argyle & 5087500 & 1960-1999 & 54 & 13 & 11 \\
\hline 10 & Roseau River near Malung & 5104500 & 1950-1999 & 58 & 17 & 32 \\
\hline 11 & Kawishiwi River near Ely & 5124480 & $1970-1999$ & 73 & 32 & 37 \\
\hline 12 & Sturgeon River near Chisholm & 5130500 & $1950-1999$ & 73 & 29 & 18 \\
\hline 13 & Warroad River near Warroad & 5139500 & 1950-1979 & 58 & 16 & 13 \\
\hline 14 & Crow Wing River at Nimrod & 5244000 & $1940-1979$ & 67 & 24 & 30 \\
\hline 15 & Long Prairie River near Long Prairie & 5245100 & 1980-1999 & 67 & 18 & 23 \\
\hline 16 & Elk River near Big Lake & 5275000 & $1940-1979$ & 73 & 19 & 23 \\
\hline 17 & Rum River near St. Francis & 5286000 & 1940-1999 & 73 & 19 & 25 \\
\hline 18 & Elk Creek near Champlin & 5287890 & 1980-1999 & 77 & 18 & 9 \\
\hline 19 & Pomme de Terre River at Appleton & 5294000 & 1940-1999 & 63 & 8 & 13 \\
\hline 20 & Chippewa River near Milan & 5304500 & 1940-1999 & 68 & 10 & 17 \\
\hline 21 & Yellow Medicine River near Granite Falls & 5313500 & 1940-1999 & 65 & 11 & 25 \\
\hline 22 & Redwood River near Marshall & 5315000 & 1950-1999 & 66 & 14 & 22 \\
\hline 23 & Cottonwood River near New Ulm & 5317000 & $1940-1999$ & 68 & 12 & 25 \\
\hline 24 & Little Cottonwood River near Courtland & 5317200 & $1980-1989$ & 71 & 17 & 20 \\
\hline 25 & Wantonwan River near Garden City & 5319500 & $1980-1999$ & 73 & 22 & 10 \\
\hline 26 & Le Sueur River near Rapidan & 5320500 & 1950-1999 & 80 & 19 & 13 \\
\hline 27 & Kettle River below Sandstone & 5336700 & 1970-1999 & 77 & 32 & 11 \\
\hline 28 & Knife River near Mora & 5337400 & $1980-1999$ & 73 & 25 & 14 \\
\hline 29 & Snake River near Pine city & 5338500 & $1960-1979$ & 75 & 27 & 17 \\
\hline 30 & Sunrise River near Stacy & 5340000 & 1950-1959 & 79 & 16 & 21 \\
\hline 31 & Straight River near Faribault & 5353800 & 1970-1999 & 81 & 25 & 19 \\
\hline 32 & North Fork Whitewater River near Elba & 5376000 & 1970-1989 & 84 & 17 & 17 \\
\hline 33 & South Fork Whitewater River near Altura & 5376500 & $1940-1969$ & 85 & 11 & 22 \\
\hline 34 & Gilmore Creek at Winona & 5379000 & 1940-1959 & 85 & 15 & 23 \\
\hline 35 & Root River near Lanesboro & 5384000 & $1950-1979$ & 84 & 15 & 22 \\
\hline 36 & Rush Creek near Rushford & 5384500 & 1950-1979 & 86 & 14 & 23 \\
\hline 37 & Des Moines River at Jackson & 5476000 & $1940-1999$ & 69 & 14 & 23 \\
\hline \multirow[t]{2}{*}{38} & Little Sioux River near Lakefield & 6603000 & 1950-1959 & 72 & 8 & 12 \\
\hline & Average & & 1955-1991 & 71 & 19 & 20 \\
\hline
\end{tabular}

Map ref. no., reference number in Fig. 1; precip., precipitation. 
snowmelt could be confused for ground-water discharge by the RORA method.

\section{Regionalization of recharge estimates using the RRR model}

Regionalization is a process by which local or basin-scale recharge estimates can be extrapolated to regional estimates covering a much larger area. Data from the UZWB, WTF, and age-dating methods are point recharge estimates, representative only of the glacial outwash near where the sites are located. The RORA results, however, represent an average recharge rate over an entire basin with greater diversity in soil type. Thus, the RORA basin-scale recharge estimates are better suited to regionalization.

Regionalization of basin-scale data in Minnesota was completed using the regional regression recharge (RRR) model of Lorenz and Delin (2007). The RRR method provides an estimate of average annual recharge for any point in the State, with the exception of peatlands. The RRR model is based on a regression of RORA recharge estimates with climate and soil data. The model synthesizes data on a spatial scale of $10-1000 \mathrm{~s}$ of $\mathrm{km}^{2}$ with a temporal scale representing the period of streamflow record, generally $1-100$ years. The RRR model recharge estimates represent the average rate within a soil association and do not reflect effects due to localized factors such as topography. The model is described in detail by Lorenz and Delin (2007) and is summarized briefly in the following paragraphs.

Lorenz and Delin (2007) proposed a linear regression model that includes a single soil variable and two climate variables. The regression equation is:

$$
\begin{aligned}
R= & -14.25+67.63^{*} \mathrm{Sy}_{\text {Rawls }}+0.6459^{*} P \\
& -0.02231^{*} \mathrm{GDD},
\end{aligned}
$$

where $R$ is average annual recharge $(\mathrm{cm} / \mathrm{yr})$ at the basin scale, $\mathrm{Sy}_{\text {Rawls }}$ is the average specific yield calculated by the Rawls method (Rawls et al., 1982) as applied to STATSGO (1994) data for the basin, $P$ is average annual precipitation $(\mathrm{cm} / \mathrm{yr})$ at the basin scale, and GDD is the number of growing degree days in degrees Celsius above $10^{\circ} \mathrm{C}$-days. For this model, $P$ and GDD were included as climatic factors to estimate the net precipitation available for recharge. Growing degree days was selected as a measure for estimating threshold instead of evapotranspiration (ET) because (1) GDD is the primary factor in estimating ET, (2) annual estimates of ET are not universally available, and (3) there are several methods of estimating ET, which would complicate use across a larger study area. The residual standard error for average recharge for Eq. (10) was $2.79 \mathrm{~cm} / \mathrm{yr}$ with 129 degrees of freedom, and the correlations within a station for different decades was 0.5422 as determined by the max-

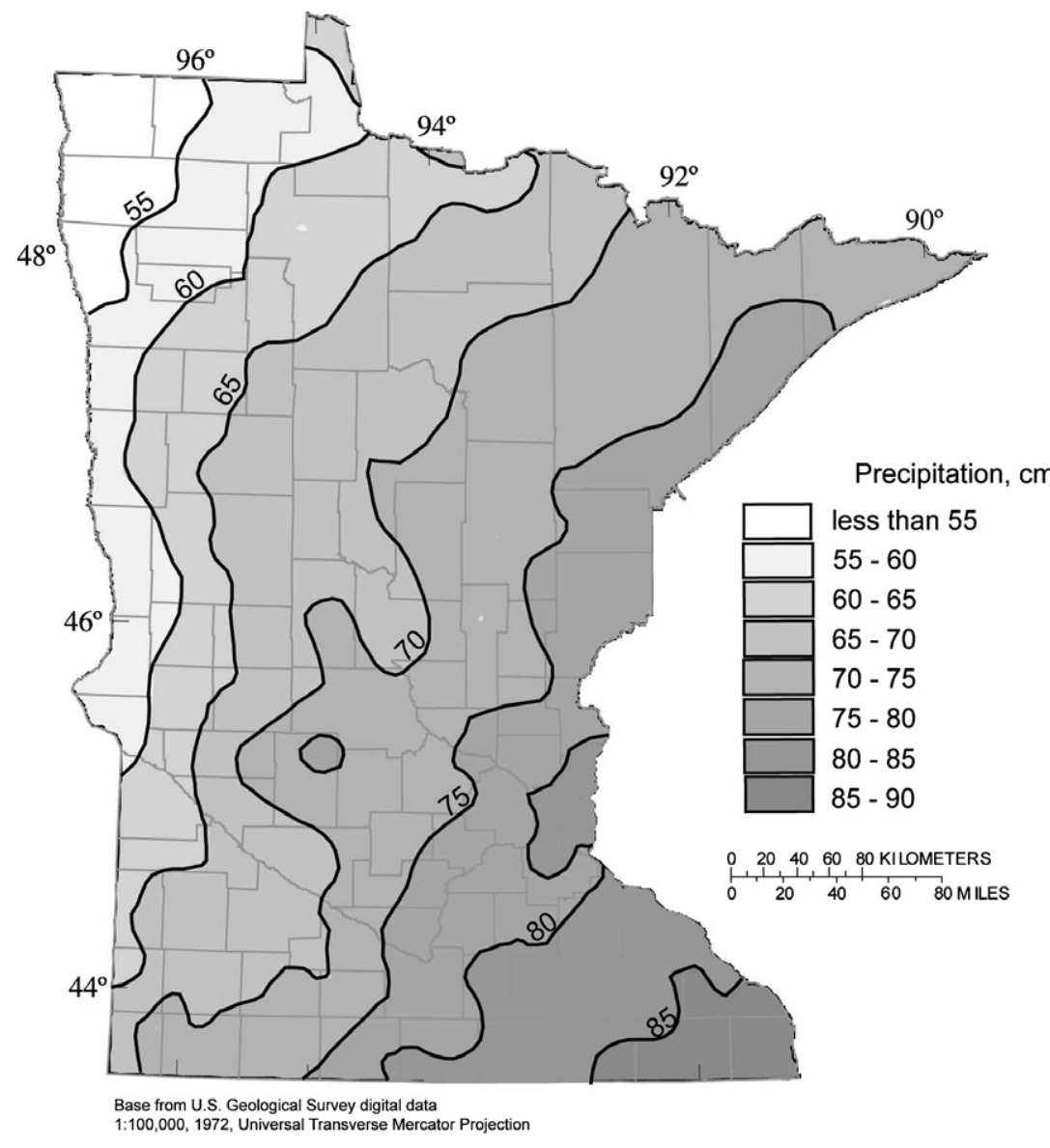

Figure 4 Average annual precipitation in Minnesota, 1971-2000 (data from Gregory Spoden, Minnesota Department of Natural Resources, written commun., 2003). 


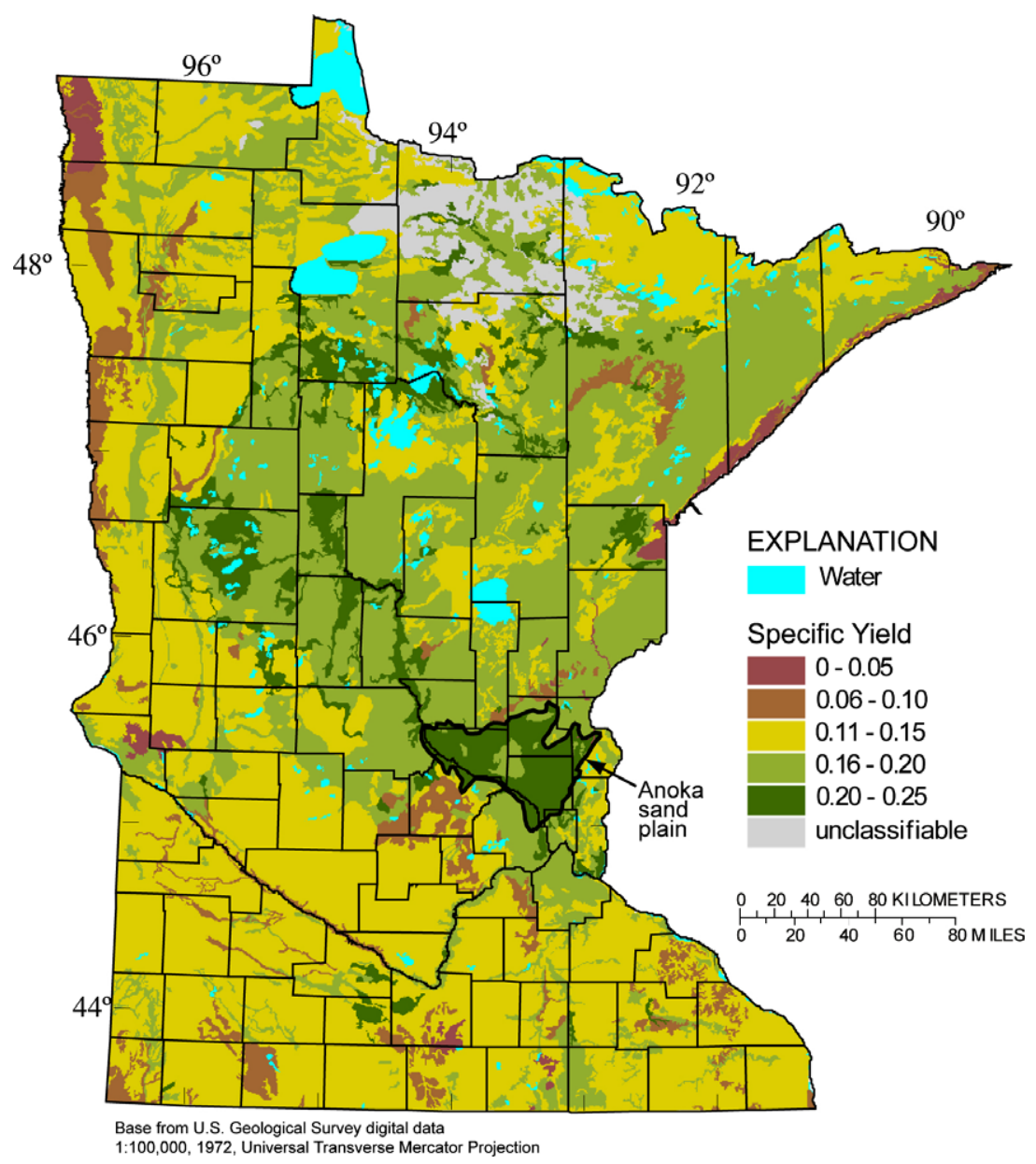

Figure 5 Spatial distribution of specific yield in Minnesota computed from STATSGO soils data using the Rawls method (Rawls et al., 1982).

imum likelihood method. The overall significance ( $p$-value) of the model is less than 0.0001 based on the likelihood ratio test between the regression model and the null model, which includes the intercept term and the correlation structure.

Evaluation of available data using the initial regression model indicated that the relation between GDD and recharge appears to be linear at GDD rates of less than about 1350 degree-days and flat at greater than $1350 \mathrm{~cm} / \mathrm{yr}$ for the selected basins. Therefore, a modified GDD was computed as the minimum of GDD and 1350 degree-days.

The RORA recharge estimates that were used to develop Eq. (10) are included in this paper as a percentage of precipitation. Precipitation rates used in the RRR model were retrieved from the Minnesota State Climatology Office (Gregory Spoden, Minnesota Department of Natural Resources, written commun., 2003) and represent interpolated annual precipitation values on a $10,000-\mathrm{m}$ grid over the entire State. The gridded data were processed to represent the average precipitation within the decadal record for each basin. The precipitation rates used in the model represent the same time periods represented by the RORA data for each basin (1940-1999) whereas the precipitation shown in Fig. 4 represents an average for 1971-2000. Growing degree day data summarized by month and year for weather stations in and near Minnesota were obtained from Shea (2006). Specific yield was selected as the soil explanatory variable in the RRR model because it relates to soil hydraulic characteristics that affect recharge. It was assumed that specific yield responds to recharge in a linear manner and could be estimated on the basis of STATSGO (1994) data. Sy $y_{\text {Rawls }}$ (Fig. 5) was estimated as the difference between the water content of saturated soil $\left(\theta_{\mathrm{s}}\right)$ and the water content of soil at field capacity $\left(\theta_{\mathrm{fc}}\right)$ (at $330 \mathrm{~cm}$ of pressure head). The Syawls, $\theta_{\mathrm{s}}$, and $\theta_{\mathrm{fc}}$ values were computed using soil texture, bulk density, amount of organic matter, and other characteristics in the STATSGO database using the method of Rawls et al. (1982).

\section{Results}

Because recharge estimates using the various methods represent different time periods (Table 1) and because precipitation and other climatic factors vary over time, a direct comparison of recharge rates cannot be reasonably made. To facilitate comparison in this paper, therefore, total annual recharge rates in the tables were computed as a fraction of annual precipitation. 


\section{Local and basin-scale recharge estimates}

\section{Unsaturated-zone water balance (UZWB) method}

On the basis of the UZWB method, average recharge rates at the measurement sites as a fraction of precipitation are: Princeton - 33\%; Bemidji - 40\%; Williams Lake - 38\%. These results are consistent with previous UZWB estimates at the Bemidji site of $24-61 \%$ (Delin and Herkelrath, 2005). These UZWB recharge estimates represent an average of three locations at the Bemidji site, two at the Princeton site, and one at the Williams Lake site. The similarity of the average UZWB recharge estimates at the Bemidji and Williams Lake sites was expected given their similarity in hydrogeologic setting and climate. The temporal variability of UZWB recharge rates as a fraction of precipitation is fairly consistent on an annual basis (Fig. 6). UZWB recharge at Bemidji well 981, however, increased slightly during the period of record for unknown reasons.

\section{Water-table fluctuation (WTF) method}

Average recharge estimated using the MRC approach to the WTF method was 30\% greater than recharge estimates made using the graphical approach and $63 \%$ greater than recharge estimates made using the RISE program approach (Table 3 ). This was expected because the MRC approach by design accounts for all recharge indicated by fluctuations of the water table, no matter how short in duration or magnitude, and also accounts for the projected recession curve. Conversely, the graphical approach may not account for the smaller recharge volumes and the RISE program approach ignores the projected recession curve.

There is a relation between unsaturated-zone thickness and estimates of recharge that were based on the WTF method. The data in Fig. 7 represent WTF recharge estimates that were based on the graphical approach used in the WTF method for all continuous-measurement wells at the Bemidji, Williams Lake, and Glacial Ridge sites for 2003. A similar relation is evident for other years as well as for the RISE and MRC approaches. There is no relation between recharge estimates and unsaturated-zone thickness for thicknesses greater than about $3.5 \mathrm{~m}$. At shallower depths to the water table, however, the WTF-estimated recharge rate increases. One possible reason for this increase may be that it takes less time for water to travel through a
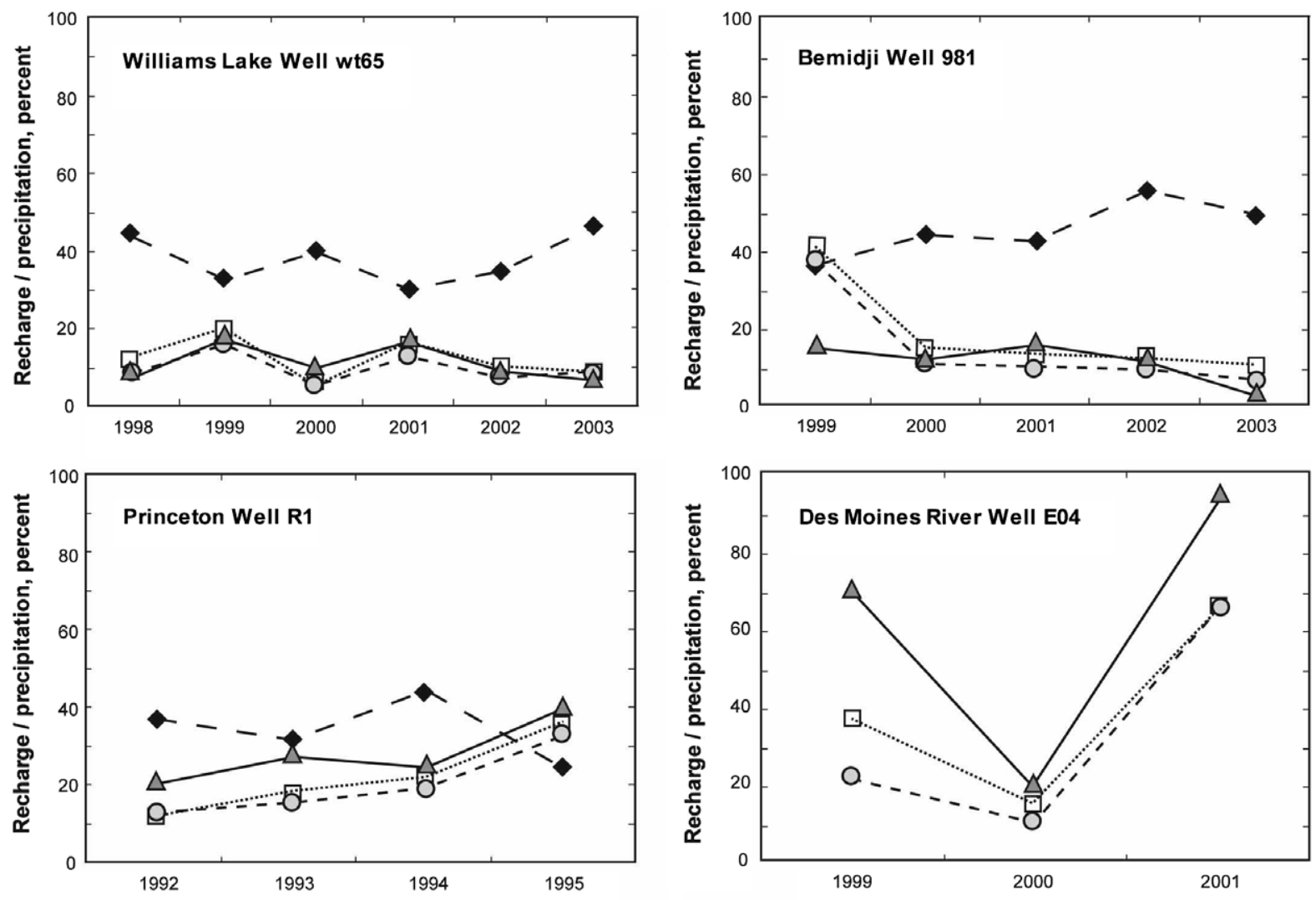

EXPLANATION

Total annual recharge:

UZWB method - - Water-table fluctuation method

RISE approach - - O -

MRC approach $\triangle$

Graphical approach …ㅁ....

Figure 6 Temporal variability of recharge using the unsaturated-zone water balance (UZWB) method and the RISE, master recession curve (MRC), and graphical approaches to the water-table fluctuation (WTF) method for selected continuously measured locations at the Williams Lake, Bemidji, Princeton, and Des Moines River sites. 
Table 3 Average recharge rates as a percentage of precipitation estimated using the water-table fluctuation method in comparison to estimated recharge from the regional regression recharge (RRR) model

\begin{tabular}{|c|c|c|c|c|c|c|c|c|c|}
\hline \multirow{3}{*}{$\begin{array}{l}\text { Map ref. } \\
\text { no. }\end{array}$} & \multirow{3}{*}{$\begin{array}{l}\text { Site name } \\
\text { or nearest } \\
\text { town }\end{array}$} & \multirow{3}{*}{$\begin{array}{l}\text { MDNR } \\
\text { well \# }\end{array}$} & \multirow{3}{*}{$\begin{array}{l}\text { Period of } \\
\text { record }\end{array}$} & \multirow{3}{*}{$\begin{array}{l}\text { Years of } \\
\text { record }\end{array}$} & \multirow[t]{3}{*}{ Sy } & \multicolumn{4}{|l|}{ Recharge rates } \\
\hline & & & & & & \multicolumn{3}{|c|}{$\begin{array}{l}\text { Water-table fluctuation method } \\
\text { approaches }\end{array}$} & \multirow[t]{2}{*}{$\begin{array}{l}\text { RRR } \\
(\%)\end{array}$} \\
\hline & & & & & & Graphical (\%) & MRC (\%) & RISE (\%) & \\
\hline 39 & Akeley & 29000 & 1971-1991 & 17 & 0.220 & 22 & 26 & 20 & 27 \\
\hline 40 & Barnesville & 14000 & 1950-1990 & 33 & 0.109 & 23 & 41 & 24 & 11 \\
\hline 41 & Bemidji $^{\mathrm{a}}$ & NA & 1994-2003 & 10 & 0.181 & 12 & 14 & 11 & 27 \\
\hline 42 & Big Lake & 71000 & 1978 & 1 & 0.103 & 11 & - & - & 19 \\
\hline 43 & Camp Ripley & 49014 & 1952-1993 & 39 & 0.070 & 20 & 31 & 15 & 22 \\
\hline 44 & Clear lake & 71006 & 1978 & 1 & 0.172 & 31 & - & - & 23 \\
\hline 45 & Cloquet & 9002 & $1952-1974$ & 22 & 0.120 & 25 & - & - & 38 \\
\hline 45 & Cloquet & 9004 & $1950-1952$ & 3 & 0.141 & 11 & 11 & 16 & 34 \\
\hline 46 & Des Moines River ${ }^{a}$ & NA & $1991-2001$ & 3 & 0.095 & 20 & 29 & 17 & 18 \\
\hline 47 & Eveleth & 69003 & 1944-1950 & 7 & 0.088 & 29 & 51 & 25 & 29 \\
\hline 48 & Glacial Ridge $^{a}$ & NA & 2003 & 1 & 0.054 & 14 & 20 & 14 & 39 \\
\hline 49 & Grand Rapids & 31000 & 1964-1967 & 3 & 0.326 & 31 & 28 & 16 & 33 \\
\hline 50 & Gray’s Bay & 27007 & 1953-1962 & 9 & 0.058 & 22 & 48 & 19 & 21 \\
\hline 51 & Hanska & 8000 & $1950-1975$ & 25 & 0.042 & 20 & 16 & 7 & 18 \\
\hline 52 & Hawley & 14004 & 1960-1966 & 7 & 0.032 & 14 & 19 & - & 15 \\
\hline 53 & Lake Bronson & 35003 & 1957-1958 & 2 & 0.023 & 10 & 8 & 6 & 13 \\
\hline 54 & Little Falls & 49017 & 1967-1971 & 5 & 0.034 & 19 & 29 & 15 & 21 \\
\hline 55 & Luce & 56017 & 1970-1971 & 2 & 0.126 & 19 & 17 & 10 & 26 \\
\hline 56 & Luxemburg & 73002 & 1978 & 1 & 0.091 & 12 & - & - & 24 \\
\hline 57 & Marshall & 42001 & $1958-1963$ & 4 & 0.060 & 24 & 32 & 23 & 9 \\
\hline 57 & Marshall & 42002 & 1958-1961 & 3 & 0.036 & 21 & - & - & 9 \\
\hline 57 & Marshall & 42005 & 1957-1962 & 6 & 0.078 & 19 & 43 & 26 & 8 \\
\hline 58 & Merrifield & 18000 & 1974-1982 & 4 & 0.096 & 20 & - & - & 27 \\
\hline 59 & Princeton $^{a}$ & NA & 1992-1995 & 4 & 0.127 & 10 & 14 & 9 & 29 \\
\hline 60 & Orrock & 71007 & 1977-1978 & 2 & 0.119 & 27 & - & - & 23 \\
\hline 61 & Osage & 3005 & 1980 & 1 & 0.225 & 11 & - & - & 29 \\
\hline 62 & Perham & 56015 & 1968-1973 & 6 & 0.096 & 11 & - & - & 18 \\
\hline 63 & Redwood Falls & 64006 & 1953-1961 & 9 & 0.030 & 17 & 25 & 13 & 16 \\
\hline 64 & Rice & 5000 & 1978-1979 & 2 & 0.255 & 57 & - & - & 20 \\
\hline 65 & Royalton & 49001 & 1974-1975 & 2 & 0.071 & 19 & - & - & 22 \\
\hline 66 & St. James & 83000 & 1966-1968 & 3 & 0.139 & 33 & 48 & 32 & 22 \\
\hline 67 & Soderville & 2014 & 1974-1976 & 3 & 0.084 & 22 & 31 & 16 & 26 \\
\hline 68 & Togo & 31001 & $1971-1978$ & 7 & 0.125 & 11 & - & - & 23 \\
\hline 69 & Verndale & 80002 & 1967-1978 & 8 & 0.132 & 19 & 21 & 16 & 24 \\
\hline 70 & Virginia & 69010 & 1955-1963 & 9 & 0.035 & 14 & 15 & 12 & 25 \\
\hline 71 & Williams Lake ${ }^{\mathrm{a}}$ & NA & 1998-2003 & 6 & 0.228 & 22 & 28 & 19 & 21 \\
\hline 72 & Willow River & 58000 & 1969-1986 & 12 & 0.162 & 18 & - & - & 32 \\
\hline 73 & Winnibigoshish & 31003 & 1944-1951 & 8 & 0.094 & 15 & 11 & 9 & 39 \\
\hline \multirow[t]{2}{*}{74} & Worthington & 53000 & $1962-1965$ & 2 & 0.059 & 25 & - & - & 17 \\
\hline & Average & NA & 1958-1966 & 7 & 0.112 & 20 & 26 & 16 & 23 \\
\hline
\end{tabular}

${ }^{a}$ USGS site where continuous water-level measurements were made; -, insufficient data to estimate recharge; MDNR, Minnesota Department of Natural Resources; MRC, Master recession curve; RISE, A. Rutledge, US Geological Survey, written commun., 2005; NA, Not applicable; Sy, specific yield; Map ref. no., reference number in Fig. 1.

thinner unsaturated zone, thus bringing more of the water to the saturated zone before it can be transpired by plants. Another possible reason is that the effective Sy decreases with proximity to the water table due to increased unsaturated-zone water content (Childs, 1960). Without taking this phenomenon into consideration Sy is overestimated. It should be noted that although a shallow water table at the Williams Lake and Glacial Ridge sites indicates a greater recharge rate, it also implies a greater ground-water ET rate. The relatively shallow depth to the water table is a likely cause of some of the anomalously large WTF recharge rates estimated for the Des Moines River site (Fig. 6).

Recharge during the summer months in this type of climate typically is minimal, although recharge can occur in the summer if precipitation, soil moisture, and other factors are favorable. Results of this study indicate that for 


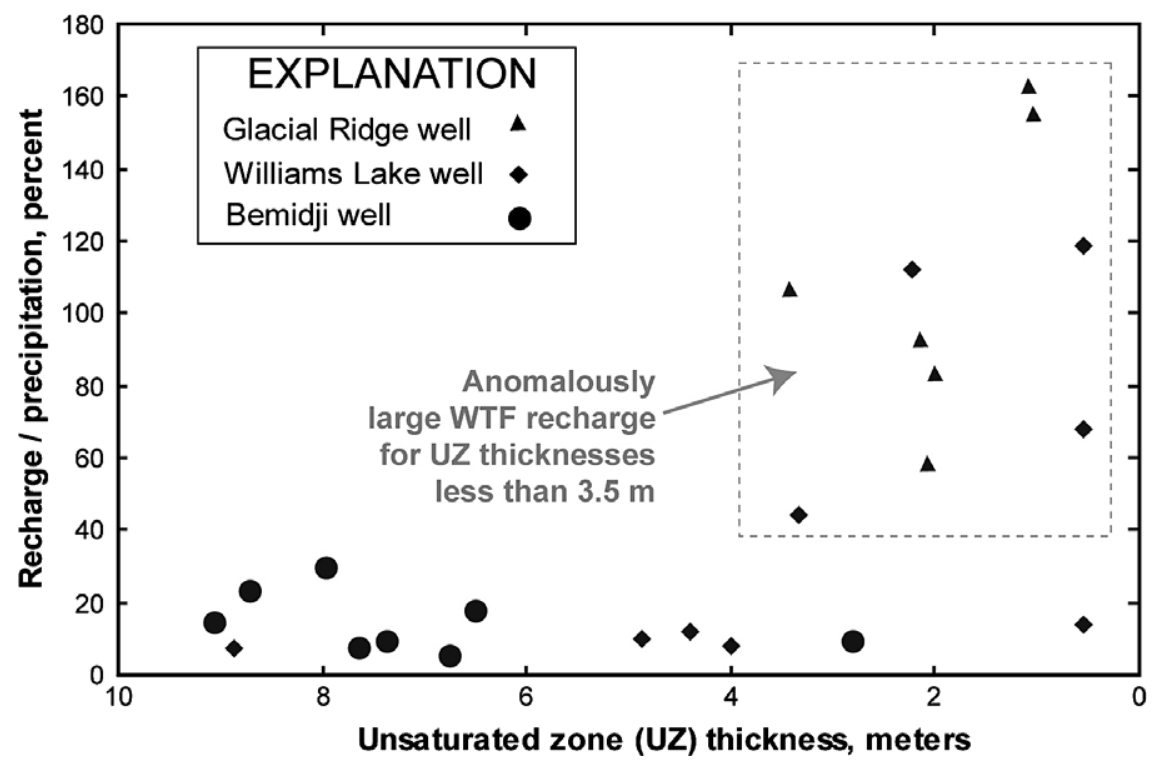

Figure 7 Inverse correlation between unsaturated-zone (UZ) thickness and recharge estimated using the water-table fluctuation (WTF) method. As the unsaturated-zone thickness decreases, the recharge rate based on the WTF method increases. The data are graphical WTF recharge estimates for all continuously measured wells at the Bemidji, Williams Lake, and Glacial Ridge sites for 2003.

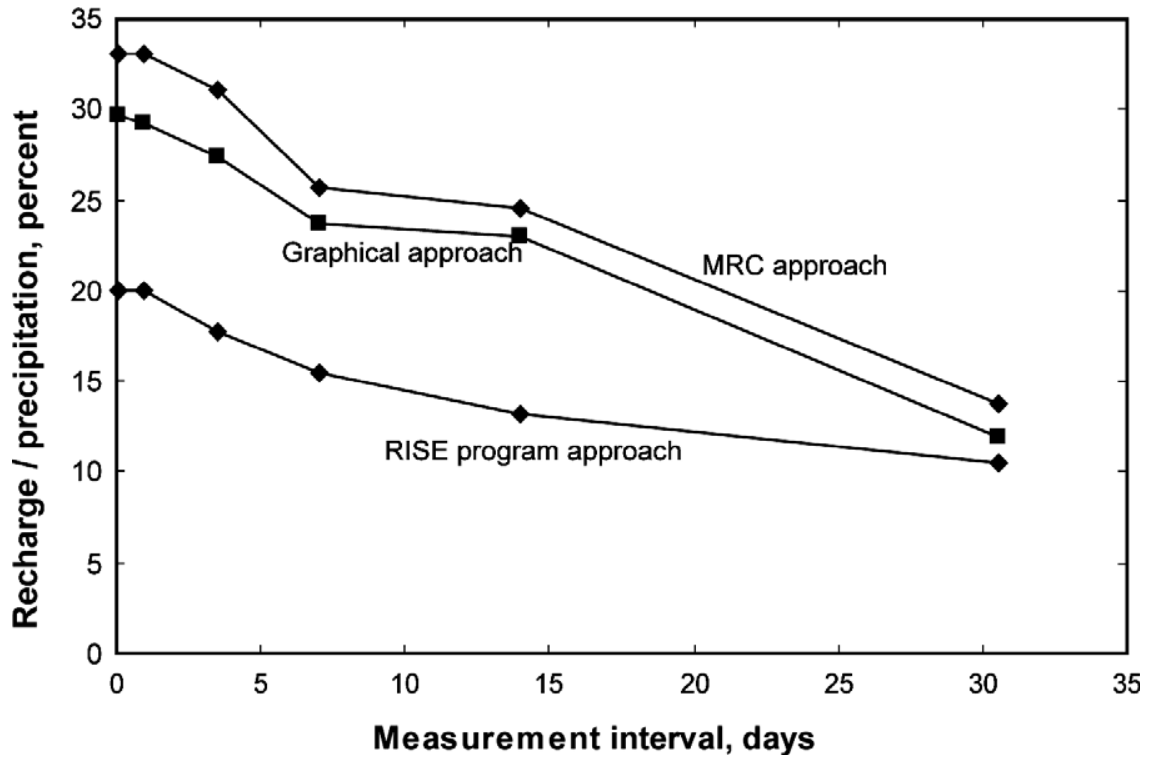

Figure 8 Effects of measurement frequency on water-table fluctuation (WTF) recharge estimates for Princeton well R2 using three approaches (data from 1993).

an accurate recharge estimate, it is necessary to collect water-level data on at least a weekly (and preferably more frequent) basis throughout the year. Unexpected recharge events simply cannot be quantified if the data have not been collected due to use of a measurement interval less frequent than weekly. Measurements made less frequently than about once per week resulted in substantially reduced recharge estimates. This result was observed for all WTF recharge estimation approaches and continuous-measurement wells at the Bemidji, Williams Lake, Princeton, Des Moines River, and Glacial Ridge sites. For example, the ef- fects of water-level measurement interval on recharge estimates at Princeton well R2 in 1993 are illustrated in Fig. 8. Water levels in this well were measured hourly throughout the year using a datalogger. By successively editing this hourly data set, smaller data sets were generated representing daily, every 3 days, weekly, bi-weekly, and monthly measurements. In using the graphical approach to estimate recharge, there was essentially no change in estimated recharge when reducing the data set from hourly to once-daily measurements; there is a $23 \%$ underestimation when reducing the data set from hourly 
Table 4 Average recharge rates as a percentage of precipitation estimated using the ground-water age-dating method in comparison to estimated recharge from the regional regression recharge (RRR) model

\begin{tabular}{|c|c|c|c|c|c|c|c|c|}
\hline $\begin{array}{l}\text { Map ref. } \\
\text { no. }\end{array}$ & $\begin{array}{l}\text { Site name or } \\
\text { nearest town }\end{array}$ & $\begin{array}{l}\text { Age-dating } \\
\text { method }\end{array}$ & $\begin{array}{l}\text { Approximate } \\
\text { range of years } \\
\text { represented }\end{array}$ & $\begin{array}{l}\text { Number } \\
\text { of wells } \\
\text { at site }\end{array}$ & $\begin{array}{l}\text { Total number } \\
\text { of years }\end{array}$ & $\begin{array}{l}\text { Average precip. } \\
(\mathrm{cm} / \mathrm{yr})\end{array}$ & $\begin{array}{l}\text { Age-dating } \\
\text { recharge } \\
\text { rate }(\%)\end{array}$ & $\begin{array}{l}\text { RRR } \\
(\%)\end{array}$ \\
\hline 75 & Atkinson & $\mathrm{SF}_{6}$ & $1996-2003$ & 1 & 7 & 79 & 49 & 34 \\
\hline 76 & Belgrade & $\mathrm{SF}_{6}$ & $1996-2003$ & 1 & 7 & 72 & 22 & 21 \\
\hline 41 & Bemidji $^{a}$ & $\mathrm{SF}_{6}$ & $1962-2003$ & 8 & 41 & 64 & 34 & 28 \\
\hline 77 & Danvers & $\mathrm{SF}_{6}$ & 1979-2003 & 1 & 24 & 67 & 7 & 16 \\
\hline 46 & Des Moines River ${ }^{a}$ & CFC -12 & 1940-1999 & 10 & 59 & 71 & 31 & 17 \\
\hline 48 & Glacial Ridge $^{a}$ & $\mathrm{SF}_{6}$ & 1989-2004 & 20 & 15 & 64 & 32 & 32 \\
\hline 59 & Princeton $^{a}$ & CFC-12 & 1949-1994 & 16 & 45 & 76 & 30 & 26 \\
\hline 78 & Parkers Prairie & $\mathrm{SF}_{6}$ & 1990-2003 & 1 & 13 & 66 & 11 & 21 \\
\hline 62 & Perham $^{a}$ & CFC-12 & 1946-1995 & 9 & 49 & 65 & 14 & 21 \\
\hline 79 & Philbrook & $\mathrm{SF}_{6}$ & $1980-2003$ & 1 & 23 & 72 & 10 & 22 \\
\hline 80 & Prairie Island ${ }^{a}$ & CFC -12 & 1950-1996 & 13 & 46 & 76 & 15 & 20 \\
\hline 81 & Rock River ${ }^{a}$ & CFC-12 & 1955-1996 & 3 & 41 & 70 & 28 & 11 \\
\hline 67 & Soderville & $\mathrm{SF}_{6}$ & 1999-2003 & 1 & 4 & 86 & 22 & 25 \\
\hline \multirow[t]{2}{*}{82} & White Bear & $\mathrm{SF}_{6}$ & 1990-2003 & 1 & 13 & 91 & 31 & 26 \\
\hline & Average & & $1973-2001$ & NA & 28 & 73 & 24 & 23 \\
\hline
\end{tabular}

${ }^{a}$ Recharge rate is based on average of multiple wells at site; NA, not applicable; Map ref. no., reference number in Fig. 1; precip., precipitation.

to weekly measurements, and a $48 \%$ underestimation when reducing the data set from hourly to monthly measurements. Similar results were obtained for the other continuous-measurement wells and for the graphical and MRC approaches to the WTF method.

We hypothesized that if daily water-level measurements for a well were collected during a single year (and accurate WTF recharge estimates were made) that accurate recharge estimates could also be made in future years where only monthly measurements are available by applying an "underestimation factor" calculated from the single year's worth of data. This hypothesis was tested by evaluating water-level data from several wells with multiple years of data. The conclusion was that underestimation of WTF recharge due to reduced measurement frequency is not constant from year to year but is variable, depending on climatic factors.

The average value of Sy calculated with Eq. (6) was 0.11. This is lower than the average $S y_{\text {Rawls }}$ value of 0.18 that was calculated from STATSGO data for each well used in the WTF method. The reasons for this are unclear. The surficial sediments represented in the STATSGO soil properties may differ texturally from aquifer sediments. Equating field capacity to moisture content at $-330 \mathrm{~cm}$ of pressure head, may underestimate true field capacity. Cassel and Nielsen (1986) suggest that for coarse-grained sediments moisture content at $-100 \mathrm{~cm}$ produces a more representative value.

\section{Age dating of ground water method}

Average recharge rates as a percentage of precipitation made on the basis of the ground-water age-dating method range from $7 \%$ at the Danvers site to $50 \%$ at the Atkinson site (Table 4). The average recharge rate for all sites is $24 \%$ and no spatial patterns of recharge are apparent across the State. The results do not indicate any bias relative to the $\mathrm{SF}_{6}$ or CFC-12 age-dating methods used.

\section{RORA method}

Recharge estimates were made for every year during the period of record for each of 38 basins (Fig. 1). The basinscale RORA recharge rates ranged from $8 \%$ to $44 \%$ of precipitation and averaged $19 \%$ of precipitation (Table 2 ). These results are within the range of recharge rates expected for the climate and hydrogeologic settings in the 38 basins (Delin et al., 2000).

\section{Regionalized recharge rates using the RRR model}

The map illustrating spatial variability of the RRR recharge rates in Minnesota (Fig. 9) was made by applying Eq. (10) to the statewide data sets of precipitation, GDD, and Sy $y_{\text {Rawls }}$ on a $10,000-\mathrm{m}$ grid over the entire State. These estimates are representative of the average recharge rates for 1971-2000 because the mean precipitation and GDD data used to generate the map were from that time period (Table 2). The RRR rates illustrated in Fig. 9 generally reflect average soil conditions as described in the STATSGO database. Local conditions, such as low permeability units at or near land surface or topographic lows, could greatly reduce or increase the estimated recharge rates. The "Unclassifiable", areas in Fig. 9 represent primarily peatlands where the organic content is too great to accurately estimate $S y_{\text {Rawls. }}$ The RRR rates in the tables were obtained using geographic information system software with the digital output used to create Fig. 9. For example, the RRR rate for the Baptism River near Beaver Bay in Table 2 was the areally weighted average of recharge for that basin overlain in Fig. 9.

\section{Comparison of RRR model to local and basin-scale results}

In addition to any deficiencies in a given method, recharge estimates may differ as a result of variations in the temporal 


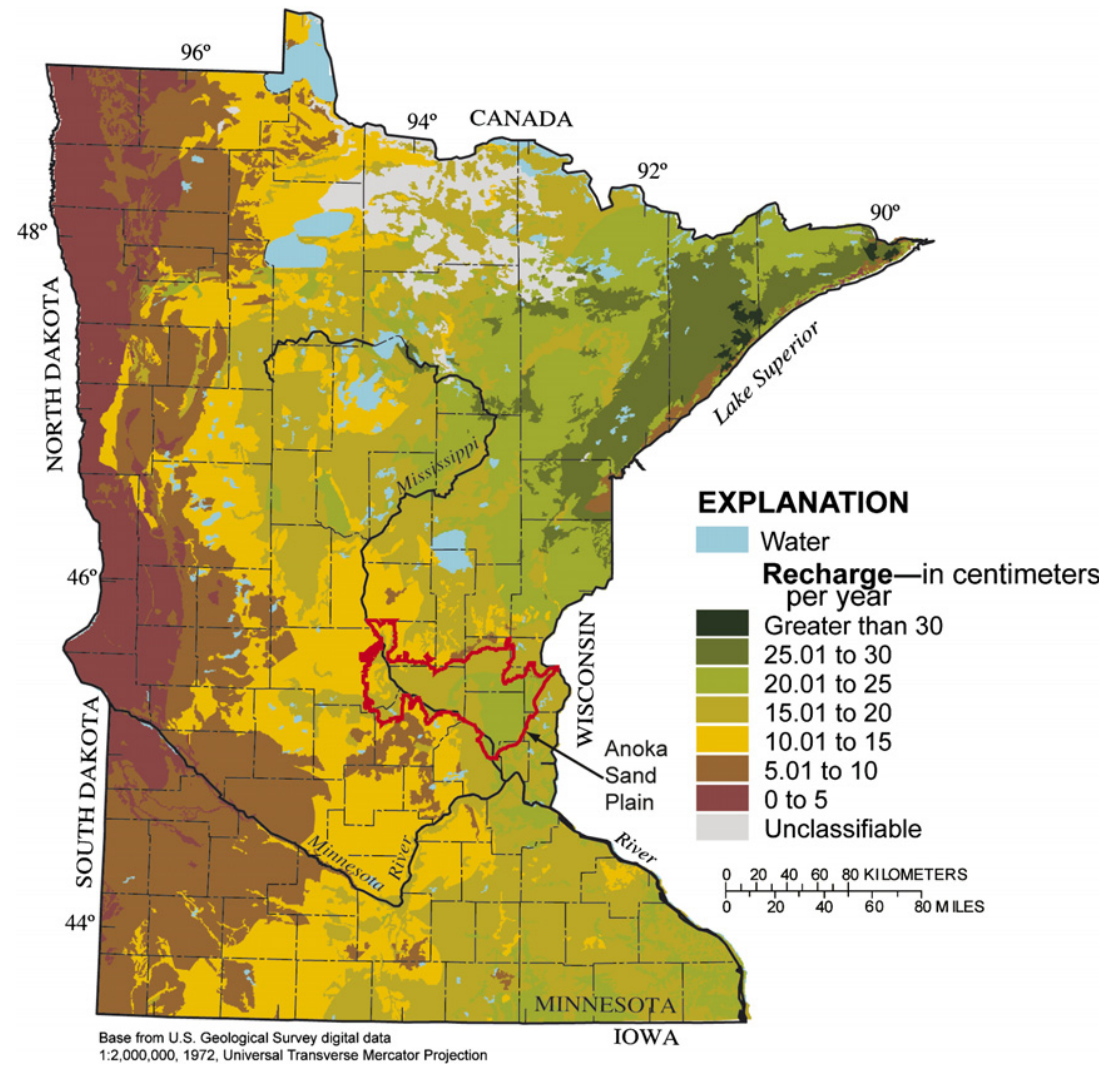

Figure 9 Average annual recharge rate to surficial materials in Minnesota (1971-2000) estimated on the basis of the regional regression recharge method.

and spatial scales of the methods (Table 1) and in the period of record for each site. Additionally, the age-dating method is limited in its spatial resolution because deeper groundwater samples, needed to establish an age gradient at a site, may represent water recharged at increasingly greater distances upgradient (Delin et al., 2000). For example, ground water sampled from a 6-m depth below the water table likely recharged the aquifer 10-100s of meters upgradient of the well whereas water sampled from $0.5-\mathrm{m}$ below

(a) RRR vs. Graphical WTF Recharge Estimates

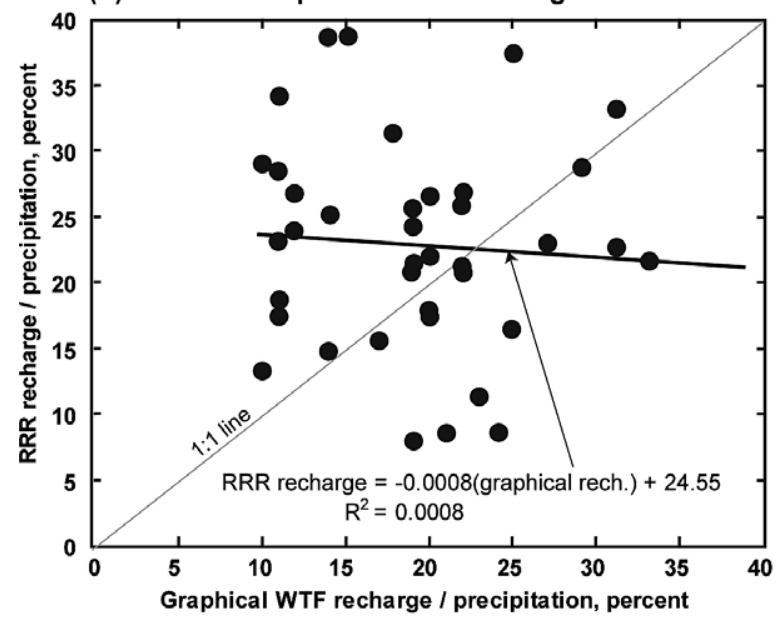

the water table likely recharged the aquifer within a few meters of the well.

The RRR rates compared least favorably to the UZWB recharge estimates. The average RRR rate of $25 \%$ of precipitation for the three UZWB sites was $72 \%$ less than the average UZWB rate of $43 \%$ of precipitation. This lack of agreement is not surprising because the UZWB rates were generally greater than the other local-scale estimates (age-dating and WTF), although they were similar in several cases.

(b) RRR vs. Age-Dating Recharge Estimates

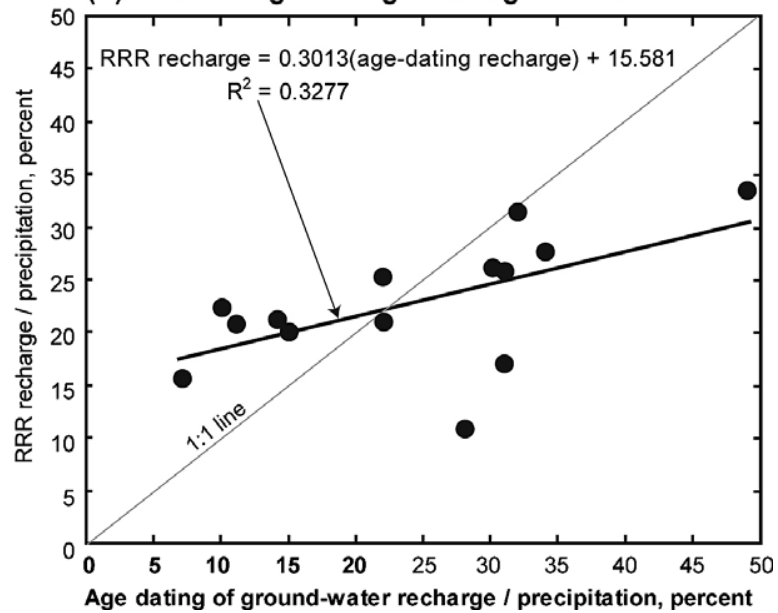

Figure 10 Correlation of the regional regression recharge (RRR) method with (a) graphical water-table fluctuation (WTF) and (b) age-dating recharge estimates. 
The average RRR rates range from $44 \%$ greater to $12 \%$ less than rates based on the three WTF approaches as a percent of precipitation, although differences for certain individual wells are much larger (Table 3). Fig. 10a illustrates the lack of correlation between RRR rates and the graphical WTF rates for individual wells. Similarly, a correlation is not evident between RRR rates with respect to results from the MRC and RISE program approaches. This is not unexpected because the WTF recharge rates were based on geologic data from a local site and water-level data collected on an annual time scale. Conversely, the RRR model synthesizes hydrogeologic data at the soil-association and basin scale (Table 2) from across the entire State of Minnesota representing a time period of about 60 years.

The average RRR rate was only about $4 \%$ less than the average based on the age dating of ground-water method; however, recharge estimates for individual wells ranged from $61 \%$ less to $229 \%$ greater (Table 4). Fig. 10b illustrates the relation between the RRR rates and the age dating of ground-water method, which is better than the relation with WTF in Fig. 10a. The better relation for the RRR versus age-dating methods likely is because both methods represent multiple years of record. In addition, the age-dating method generally utilized data representing a larger area than that of the WTF method.

The average RRR rate compared most favorably with the RORA recharge rates, being only about $5 \%$ greater (Table 2 ). This result is not surprising because the RRR model was based on the RORA data. The weighted average of the RRR rates as a percentage of precipitation for individual basins was as much as $22 \%$ less to $39 \%$ greater than the various RORA estimates within each basin (Table 2), which likely resulted from local heterogeneities within the basin that were represented in the RORA results but not in the RRR results.

\section{Discussion}

Because the actual recharge rate is never known with $100 \%$ certainty at a given location, use of multiple recharge estimation methods is beneficial. No single method can be termed the "best" at estimating recharge due to: (1) spatial and temporal variability in the various independent variables (Table 1); (2) inherent limitations for each method (as described earlier); (3) limitations on the availability of input data in a given area; and (4) variability in the uses or applications of the recharge estimates. Nevertheless, several conclusions can be gleaned from this study about the advantages, disadvantages, and limitations of the methods employed.

Of the methods used in this study, the WTF method was the simplest and easiest to apply. Where water-level data are already available this method is also the least expensive to apply, although results indicate that at least a weekly measurement frequency is required to avoid an unacceptable underestimation of the recharge rate. Of the WTF approaches used, RISE is the most reproducible; any user that applies the program properly should generate exactly the same recharge rate as the next user. Recharge estimates on the basis of the MRC approach were consistently greater than recharge estimates made using the graphical and RISE approaches. The graphical WTF approach requires the most subjectivity on the part of the user in projecting the ground-water recession curve and thus is the least reproducible.

The ground-water age-dating method also is easy to apply, however it requires accurate determination of ground-water age using sophisticated and not-readily available laboratory methods. The costs associated with the collection and analysis of samples may be a deterrent to use of this method. In addition, there are many uncertainties associated with the age dating of water (e.g. Busenberg and Plummer, 1992, 2000).

The RORA method, as well as similar recession-curve-displacement techniques, has an advantage over the site-specific methods in that it yields a recharge rate that is representative of an entire basin (Table 1). Generation of a recharge rate representative of this large an area makes this method conducive to regionalization methods, such as RRR, whereas local-scale recharge estimates are highly variable and may be difficult to transfer from one location to another. High-quality, long-term continuous streamflow records are required for the RORA method. If missing values are estimated, uncertainty of the results increases. The RORA method is not applicable in arid or semiarid areas where perennial streams do not exist. Although RORA assumes that streamflow recession is caused by ground-water discharge, this might not be the case. Slow drainage to streams from bank storage, wetlands, surface-water bodies, soils, and snowmelt runoff can exceed ground-water discharge during recession periods (Halford and Mayer, 2000; Rutledge, 2000), and could be confused for ground-water discharge by the RORA method.

Recharge estimates made on the basis of the UZWB method were inconsistent with the results from the other methods (Fig. 6). Based on results of this and previous studies, recharge rates in semi-humid climates generally fall in the range of about $10-40 \%$ of precipitation (e.g. Delin et al., 2000). However, the UZWB estimates generally fall above or in the upper end of this range and are unreasonably large in some cases. In addition, the cost of collecting data for the UZWB method is perhaps the greatest of the methods tested, due to the labor and equipment needed to collect soil-moisture data at multiple depths in the unsaturated zone. In addition, the UZWB method yields a point recharge estimate, representative of only about a 1$\mathrm{m}^{2}$ area, which is a drawback for some applications.

The RRR model, as applied in this study, should be relatively easy to construct in other humid areas of the world where regional databases for soils (such as STATSGO), precipitation, and growing degree days are available. These data bases are available across the entire United States, and presumably in other areas of the world. The only other data needed to construct a RRR model is a set of independent recharge estimates on a local or basin scale throughout the area of interest. If a RRR model has already been constructed, the spatially-variable recharge estimates it generates could easily be used as input to a ground-water flow model; RRR model results currently are being applied for this purpose in USGS studies elsewhere. These RRR estimates, variable at the soil association scale, are preferable for ground-water flow model input compared to the conventional use of local- or basin-scale recharge estimates that typically are assumed to be constant over large areas. 
Numerous factors influence the spatial variability of recharge including physical characteristics of the soil, vegetation cover, land use, topography, water content of surface materials, climate variability, and depth of the confining layers and aquifers. Focused recharge of water in depressional areas due to runoff from surrounding upland areas also is an important local factor affecting recharge variability. These small-scale variabilities in recharge are lost or smoothed out when these basin-scale recharge estimates are regionalized. Consequently, the recharge rates estimated using the RRR method should be used with caution for localized estimates of recharge. Average values of precipitation, recharge, and other variables were used to construct the maps and regression equations. Thus, actual recharge rates will vary from year to year depending on climate and weather patterns.

\section{Spatial variability in recharge}

\section{Large-scale variability}

Large-scale trends in recharge across Minnesota reflect climatic variations. There is a strong relation between RRR rates (Fig. 9) and average precipitation (Fig. 2). Where precipitation is least in the northwestern part of the State (50$65 \mathrm{~cm} / \mathrm{yr})$, recharge also is least $(0-5 \mathrm{~cm} / \mathrm{yr})$. Similarly, recharge increases in the eastern part of the State to greater than about $15 \mathrm{~cm} / \mathrm{yr}$ as precipitation increases to greater than about $75 \mathrm{~cm} / \mathrm{yr}$. In the southeastern part of the State, where precipitation is even greater than in northeastern Minnesota, RRR recharge rates are small. The relation between RRR recharge rates and $\mathrm{Sy}_{\text {Rawls }}$ (Fig. 5) is not as evident as with precipitation. Nevertheless, sand-plain areas in the east-central part of the State, with Sy $y_{\text {Rawls }}$ primarily in the $0.20-0.25$ range, correspond well with RRR recharge rates in the $15-25 \mathrm{~cm} / \mathrm{yr}$ range.
Large-scale trends are evident in the RORA basin-scale data, with recharge greatest in the northeastern part of the State and decreasing to the southwest (Table 2; Fig. 1). This trend results to a large degree from smaller runoff and ET rates in the northeast (Baker et al., 1979).

Large-scale trends in recharge are not readily evident in the WTF results (Table 3; Fig. 1). The greatest recharge rates (greater than $20 \%$ of annual precipitation) are located in the east-central trending toward the southwestern parts of the State. This area of greater WTF recharge does not relate well to patterns of precipitation or Sy $y_{\text {Rawls. }}$ Large-scale trends in recharge are also not readily evident in the ground-water age dating results (Table 4; Fig. 1). The least recharge rates (less than $20 \%$ of annual precipitation) are located in the west-central part of the State with most of the remaining sites having recharge between $20 \%$ and $40 \%$ of precipitation. This area of least ground-water age-dating recharge does not relate well to patterns of precipitation or Sy $y_{\text {Rawls. }}$ Local anomalies likely are the result of local heterogeneities in soils and topography rather than part of a large-scale trend as noted earlier.

\section{Small-scale variability}

Small-scale variability in recharge in Minnesota is related largely to variability in soil properties and land-surface topography. Focused recharge of water in depressional areas due to runoff from surrounding upland areas has been identified by Delin et al. (2000) as an important contribution to spatial variability in recharge. Evidence of this type of small-scale variability in recharge was observed at several of the intensive data-collection sites. For example, $37 \%$ of the continuously measured wells at the Bemidji site are located in lowland areas, where average graphical WTF recharge is $21 \%$ of precipitation compared to $15 \%$ in upland areas.

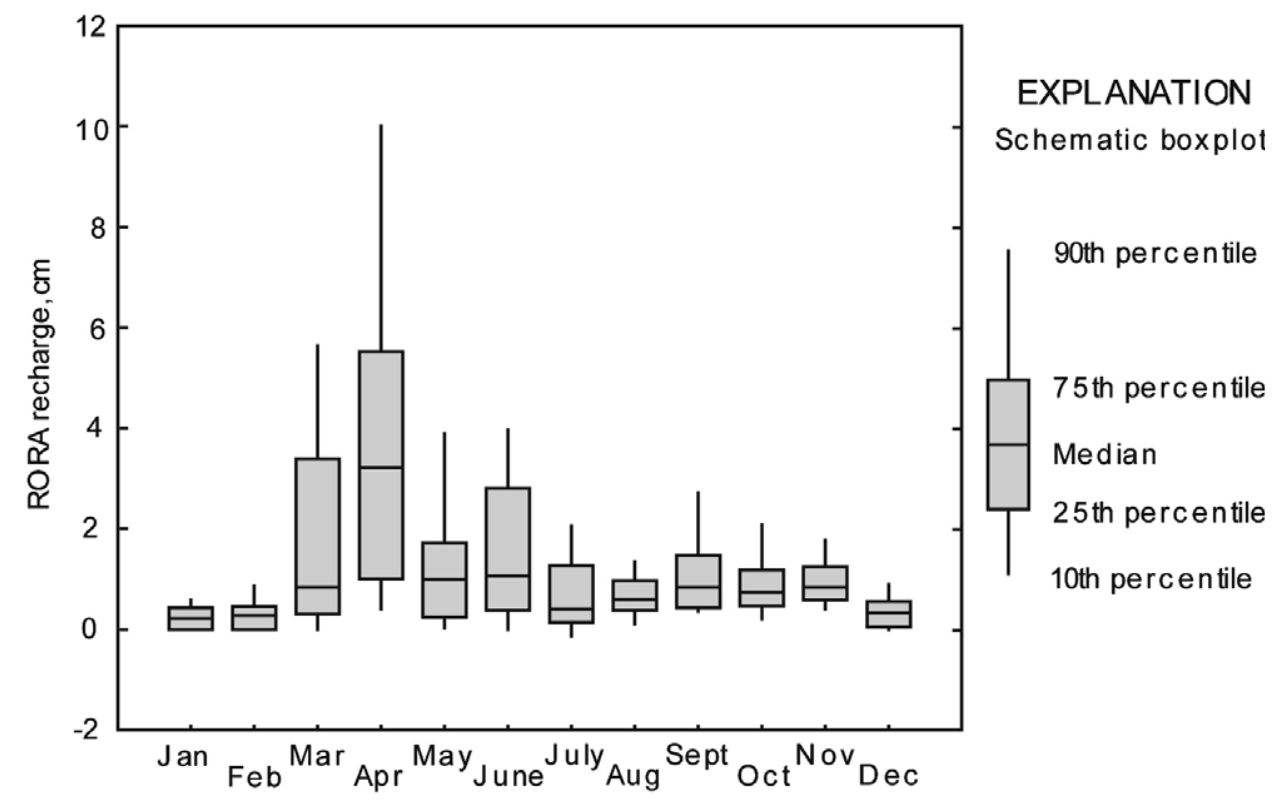

Figure 11 Statistical summary of total monthly recharge for Elk River near Big Lake, Minnesota for 1940-1979, estimated using the RORA method. 

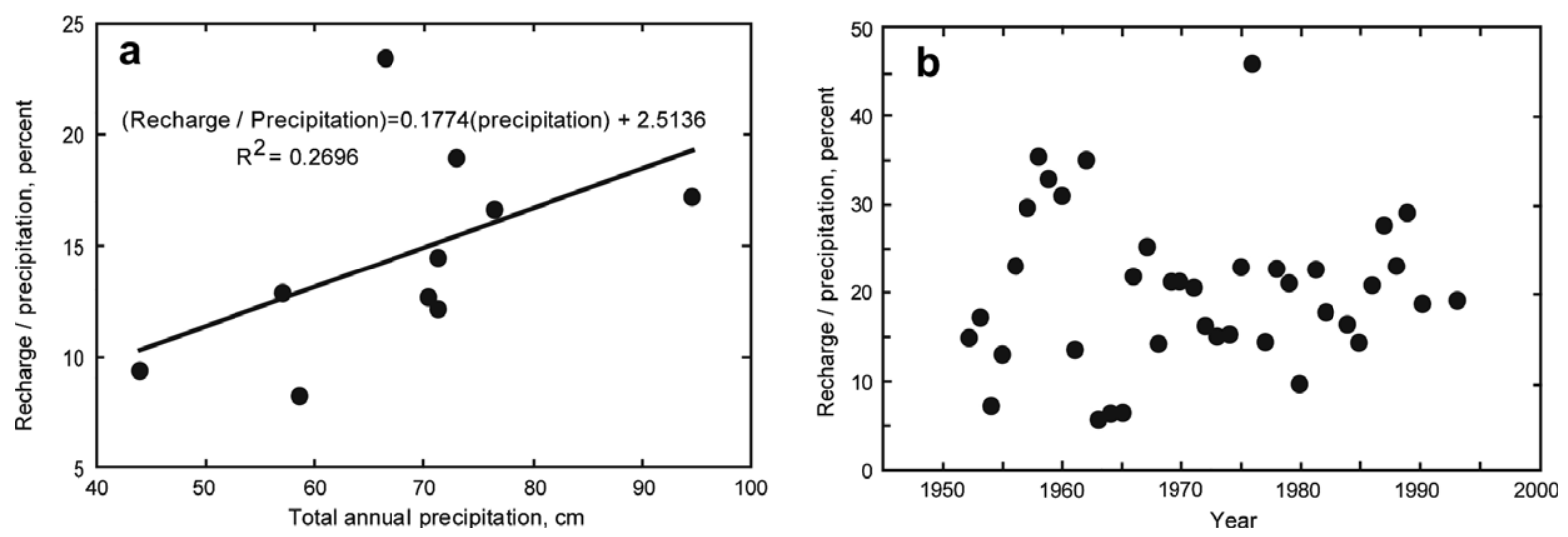

Figure 12 Graphical water-table fluctuation (WTF) recharge divided by precipitation versus: (a) total annual precipitation for Bemidji well 310d; (b) year for MDNR well 49014.

\section{Temporal variability in recharge}

\section{Intra-annual variability}

Ground-water recharge varies seasonally on the basis of several factors, including climate, antecedent soil-moisture conditions, soil hydraulic properties, and depth to the water table. An example of this seasonal variability using the RORA method is illustrated in Fig. 11, a boxplot statistical summary of total monthly recharge for Elk River near Big Lake, Minnesota for 1940-1979. As expected, recharge was greatest in the spring, which typically included 80$90 \%$ of total annual recharge at any given site in Minnesota. A much smaller secondary period of recharge typically occurred in the fall. The data in Fig. 11 are typical of monthly variability in recharge throughout Minnesota, regardless of estimation method.

\section{Inter-annual variability}

The RRR method provides an estimate of average annual recharge for any point over a region. A tacit assumption in this approach is that recharge does not change from year to year. In reality recharge does vary, primarily in response to changes in climate patterns (Fig. 6). Fig. 12a shows how graphical WTF recharge increased with precipitation for Bemidji well 310d. This same relation also is apparent for MDNR well 49014 (Fig. 12b), which has the longest period of record (39 years) of the wells used in this study. The average of graphical WTF recharge to precipitation for this well was $20 \%$ over that period (coefficient of variation $43 \%$ ), in good agreement with the RRR estimate of $22 \%$ (Table 3 ). MDNR well 49014 is typical of the other wells in this study. The average ratio of recharge to precipitation for all wells and years is $20 \%$, with a coefficient of variation of $45 \%$.

In addition to variations in response to climate patterns, recharge also can vary in response to changes in land use. For example, studies by Gebert and Krug (1996) and Juckem (2003) indicated statistically significant changes in streamflow and recharge, respectively, due to changes in agricultural practices in southwestern Wisconsin.

\section{Summary and conclusions}

Estimates of ground-water recharge for Minnesota from a regional regression recharge (RRR) model were compared to estimates based on three local-scale methods and one basin-scale method. Local-scale methods were based on an unsaturated-zone water balance (UZWB), water-table fluctuations (WTF) using three approaches, and age dating of ground water. A fourth method (RORA) is a basin-scale analysis of streamflow records using a recession-curve-displacement technique. The RORA recharge estimates, plus climate and soils data, were the basis for the RRR model. The RRR model provides an estimate of average annual recharge for any point in the State of Minnesota, and a similar model could be constructed for other areas of the world.

The RRR model, as applied in this study, should be relatively easy to construct in other humid areas of the world where regional databases for soils, precipitation, and growing degree days are available. The only other data that one needs to construct a RRR model is a set of independent recharge estimates based on local- or basin-scale estimates from throughout the area of interest. Recharge estimates using the RRR model could be a good source of input for regional ground-water flow models; RRR model results currently are being applied for this purpose in USGS studies elsewhere.

The WTF method is the simplest and easiest to apply, of the methods used in this study. Because water-level data are readily available this method could also be considered the least expensive to apply, although results of this study indicate that at least a weekly measurement frequency is required to avoid an unacceptable underestimation of the recharge rate. Recharge estimates made on the basis of the UZWB method were inconsistent with the results from the other methods, and are considered unreasonably large in some cases. The RORA method has an advantage over the site-specific methods in that it yields a recharge rate that is representative of a relatively large area. This makes the RORA results conducive to regionalization using the RRR method.

Despite the various limitations of each of the methods used in this study, estimated recharge rates normalized to precipitation at a given site fall on average within about $60 \%$ of each other. This degree of agreement is noteworthy particularly in consideration of the different temporal and spatial scales represented by the various methods. Although good agreement among methods does not necessarily imply accuracy, it supports greater confidence in the results. 


\section{Acknowledgements}

This research was supported primarily through the US Geological Survey (USGS) Ground Water Resources Program (Grannemann, 2001; Dennehy, 2005) with additional support through the USGS National Research Program and the Minnesota Department of Natural Resources. The efforts of USGS employees Tom Winter, Lehne Franke, Don Rosenberry, Dallas Hudson, Tim Cowdery, Greg Williams, Paul Oduro, Erik Smith, Kim Reierson, and Stephanie Johnson are appreciated for their assistance with technical consultation as well as various analyses and data collection associated with this paper. The authors thank US Geological Survey technical reviewers Randy Hunt and Dennis Risser as well as two anonymous reviewers for providing valuable comments that significantly improved this paper. Use of brand, firm, or trade names in this paper is for identification purposes only and does not constitute endorsement by the US Government.

\section{References}

Arnold, J.G., Muttiah, R.S., Srinivasan, R., Allen, P.M., 2000. Regional estimation of base flow and groundwater recharge in the Upper Mississippi river basin. Journal of Hydrology 227, 2140.

Baker, D.G., Kuehnast, E.L, Zandlo, J.A., 1985. Climate of Minnesota-Part XV, Normal Temperatures (1951-1980) and their Application. University of Minnesota Technical Bulletin AD-SB2777-1985.

Baker, D.G., Nelson, W.W. Kuehnast, E.L. 1979. Climate of Minnesota-Part XII, The Hydrologic Cycle and Soil Water. University of Minnesota Technical Bulletin 322.

Böhlke, J.K., 2002. Groundwater recharge and agricultural contamination. Hydrogeology Journal 10, 153-179.

Busenberg, E., Plummer, L.N., 1992. Use of chlorofluorocarbons (CCl3F and $\mathrm{CCl} 2 \mathrm{~F} 2)$ as hydrologic tracers and age-dating tools: Example-The alluvium and terrace system of central Oklahoma. Water Resources Research 28, 2257-2284.

Busenberg, Eurybiades, Plummer, L., 2000. Dating young groundwater with sulfur hexafluoride: Natural and anthropogenic sources of sulfur hexafluoride. Water Resources Research 36 (10), 3011-3030.

Cassel, D.K., Nielsen, D.R., 1986. Field capacity and available water capacity. In: Klute, A. (Ed.), Methods of Soil Analysis, second ed. American Society of Agronomy, Madison, WI, pp. 901-926.

Childs, E.C., 1960. The nonsteady state of the water table in drained land. Journal of Geophysical Research 65, 780-782.

Cowdery, T.K., 1999. Water resources of the Prairie Island Indian Reservation, Minnesota, 1994-97. Water-Resources Investigations Report 99-4069. US Geological Survey.

Cowdery, 2005. Hydrogeology and ground-water/surface-water interactions in the Des Moines River Valley, southwestern Minnesota, 1997-2001. Scientific Investigations Report 20055219. US Geological Survey.

Crosbie, R.S., Binning, P., Kalma, J.D., 2005. A time series approach to inferring groundwater recharge using the water table fluctuation method. Water Resources Research 41 (1), 19.

Delin, G.N., Herkelrath, W.N., 2005. Use of soil-moisture probes to estimate ground-water recharge at an oil-spill site. Journal of American Water Resources Association 41 (6), 1259-1277.

Delin, G.D., Healy, R.W., Landon, M.K., Böhlke, J.K., 2000. Effects of topography and soil properties on recharge at two sites in an agricultural field. Journal of American Water Resources Association 36 (6), 1401-1416.
Delin, G.N., Landon, M.K., Nelson, K.J., Wanty, R.B., Healy, R.W., Olsen, H.W., Böhlke, J.K., Schroyer, B.R., Capel, P.D., 1997. Hydrogeologic and water-quality data used to evaluate the effects of focused recharge ground-water quality near Princeton, Minnesota, 1991-95. Open-File Report 97-21. US Geological Survey.

Dennehy, K.F. 2005. Ground-water resources program. Fact Sheet 2005-3097. US Geological Survey.

Dumouchelle, D.H., Schiefer, M.C., 2002. Use of streamflow records and basin characteristics to estimate ground-water recharge rates in Ohio. Ohio Department of Natural Resources Bulletin 46.

Freeze, R.A., Cherry, J.A., 1979. Groundwater. Prentice-Hall, Englewood Cliffs, NJ.

Gebert, W.A., Krug, W.R., 1996. Streamflow trends in Wisconsin's Driftless Area. Journal of American Water Resources Association 32 (4), 733-744.

Grannemann, N.G. 2001. US Geological Survey ground-water resources program, 2001. Fact Sheet 056-01. US Geological Survey.

Gvirtzman, H., Ronen, D., Magaritz, M., 1986. Anion exclusion during transport through the unsaturated zone. Journal of Hydrology 87, 267-283.

Hall, D.W., Risser, D.W., 1993. Effects of agricultural nutrient management on nitrogen fate and transport in Lancaster County, Pennsylvania. Water Resources Bulletin 29, 55-76.

Halford, K.J., Mayer, G.C., 2000. Problems associated with estimating ground water discharge and recharge from streamdischarge records. Journal of Ground Water 38 (3), 331-342.

Healy, R.W., Cook, P.G., 2002. Using groundwater levels to estimate recharge. Hydrogeology Journal 10, 91-109.

Heppner, C.S., Nimmo, J.R., 2005. A computer program for predicting recharge with a master recession curve: US Geological Survey Scientific Investigations Report 2005-5172, 8p.

Holtschlag, D.J., 1996. A generalized estimate of ground-water recharge rates in the lower peninsula of Michigan. Open-File Report 96-593. US Geological Survey.

Juckem, P.F., 2003. Spatial patterns and temporal trends in groundwater recharge, upper Coon Creek Watershed, southwest Wisconsin. M.S. thesis, Department of Geology and Geophysics, University of Wisconsin-Madison.

Lerner, D.N., 2002. Identifying and quantifying urban recharge: a review. Hydrogeology Journal. 10, 143-152.

Lindgren, R.J., Landon, M.K., 2000. Effects of ground-water withdrawals on the Rock River and associated valley aquifer, eastern Rock County, Minnesota. Water-Resources Investigations Report 98-4157. US Geological Survey.

Lorenz, D.W., Delin, G.N., 2007. Regional estimation of groundwater recharge in Minnesota using a multiple regression model. Ground Water 45 (2).

Meinzer, O.E. 1923. The occurrence of groundwater in the United States with a discussion of principles. Water-Supply Paper 489. US Geological Survey.

Memon, B.A., 1995. Quantitative analysis of springs. Environmental Geology 26, 111-120.

Nimmo, J.R., Healy, R.W., Stonestrom, D.A., 2005. Aquifer recharge. In: Anderson, M., Bear, J. (Eds.), Encyclopedia of Hydrological Science, vol. 4. Wiley, Chichester, UK, pp. 2229-2246.

Rawls, W.J., Brakensiek, D.L., Saxton, K.E., 1982. Estimation of soil water properties. Transactions of the American Society of Agricultural Engineers 25, 1316-1320.

Risser, D.W., Gburek, W.J., Folmar, G.J., 2005. Comparison of methods for estimating ground-water recharge and base flow at a small watershed underlain by fractured bedrock in the eastern United States. Scientific Investigations Report 2005-5038. US Geological Survey.

Robins, N.S. 1998. Groundwater pollution, aquifer recharge and vulnerability. Geological Society of London Special Publication. vol. 130. 
Rorabaugh, M.I., 1960. Use of water levels in estimating aquifer constants in a finite aquifer. International Association of Scientific Hydrology Commission of Subterranean Waters 52, 314-323.

Rorabaugh, M.I., 1964. Estimating changes in bank storage and ground-water contribution to streamflow. International Association of Science Hydrology 63, 432-441.

Rutledge, A.T. 1998. Computer programs for describing the recession of ground-water discharge and for estimating mean groundwater recharge and discharge from streamflow records-update. Water-Resources Investigations Report 98-4148. US Geological Survey.

Rutledge, A.T., 2000. Considerations for Use of the RORA Program to Estimate Ground-Water Recharge from Streamflow Records. Open-File Report 00-156. US Geological Survey.

Scanlon, B.R., Tyler, S.W., Wierenga, P.J., 1997. Hydrologic issues in arid systems and implications for contaminant transport. Review Geophysics 35, 461-490.

Scanlon, B.R., Healy, R.W., Cook, P.G., 2002. Choosing appropriate techniques for quantifying groundwater recharge. Hydrogeology Journal 10, 18-39.

Shea, Sam, 2006. Written and Electronic Communication, April, 2006. Midwestern Regional Climate Center, Champaign, Illinois.

Sims, P.K., Morey, G.B., 1972. Geology of Minnesota: A Centennial Volume. Minnesota Geological Survey.
Sophocleous, M.A., 1992. Groundwater recharge estimation and regionalization: the Great Ben Prairie of central Kansas and its recharge statistics. Journal of Hydrology 137 (1-4), 113140.

STATSGO, 1994. State Soil Geographic (STATSGO) data base for Minnesota. US Department of Agriculture, Natural Resources Conservation Service, Fort Worth, Texas.

Stoner, J.D., Cowdery, T.K., Puckett, L.J. 1997. Ground-water age dating and other tools used to assess land-use effects on water quality. Water-Resources Investigations Report 97-4150. US Geological Survey.

Szilagyi, J., Harvey, F.E., Ayers, J.F., 2005. Regional estimation of total recharge to ground water in Nebraska. Ground Water 43 (1), 63-69.

Tyler, S.W., Chapman, J.B., Conrad, S.H., Hammermeister, D.P., Bout, D.O., Miller, J.J., Sully, M.J., Ginanni, J.M., 1996. Soilwater flux in the southern Great Basin, United States: temporal and spatial variations over the last 120,000 years. Water Resources Research 32, 1481-1499.

Vogel, J.C., 1967. Investigation of groundwater flow with radiocarbon. In: Isotopes in Hydrology. International Atomic Energy Agency, Vienna, pp. 355-368.

Walton, W.C., 1970. Groundwater Resource Evaluation. McGrawHill, New York. 